See discussions, stats, and author profiles for this publication at: https://www.researchgate.net/publication/350856961

\title{
Assessment of the genetic diversity of groundnut (Arachis hypogaea L.) genotypes for kernel yield, oil and fodder quantity and quality under drought conditions
}

Article · April 2021

CITATIONS

0

6 authors, including:

Seltene Abady

Haramaya University

12 PUBLICATIONS 54 CITATIONS

SEE PROFILE

Janila Pasupuleti

International Crops Research Institute for Semi Arid Tropics 130 PUBLICATIONS 1,560 CITATIONS

SEE PROFILE
READS

100
Hussein Shimelis

University of KwaZulu-Natal

396 PUBLICATIONS 2,974 CITATIONS

SEE PROFILE

Jacob Mashilo

Limpopo Department of Agriculture and Rural Development 58 PUBLICATIONS 219 CITATIONS

SEE PROFILE

Some of the authors of this publication are also working on these related projects:

Empowerment of women through water use security, land use security and knowledge generation for improved household food security and sustainable rural livelihoods in selected areas in limpopo View project

Plant physiology View project 
Plant Genetic Resources

\title{
Assessment of the genetic diversity of groundnut (Arachis hypogaea L.) genotypes for kernel yield, oil and fodder quantity and quality under drought conditions
}

\author{
Seltene Abadya ${ }^{1,2}$ (i) \\ Hussein Shimelis ${ }^{1}$ () \\ Sunil Chaudhari $^{3}{ }^{\circledR}$ ( ) $\quad$ Surendra S. Manohar
}

Janila Pasupuleti ${ }^{3}$

Jacob Mashilo ${ }^{1}$

${ }^{1}$ African Centre for Crop Improvement (ACCI), School of Agricultural, Earth and Environmental Sciences, University of KwaZulu-Natal, Scottsville, South Africa

${ }^{2}$ School of Plant Sciences, Haramaya University, P.O. Box 138, Dire Dawa, Ethiopia

${ }^{3}$ International Crops Research Institute for the Semi-Arid Tropics (ICRISAT),

Hyderabad, Telangana, India

\section{Correspondence}

Seltene Abady, School of Plant Sciences, Haramaya University, P.O. Box 138, Dire Dawa, Ethiopia.

Email: selteabady@yahoo.com

Assigned to Associate Editor Endang Septiningsih.

Funding information Haramaya University; University of KwaZulu-Natal; Organization of the Petroleum Exporting Countries (OPEC) Fund for International Development (OFID); International Foundation for Science (IFS)

\begin{abstract}
The objective of this study was to determine drought tolerance, kernel (KY) and fodder yield and quality amongst diverse groundnut genotypes for direct production or breeding. Hundred genotypes were evaluated at ICRISAT, India during 2018-2019 and 2019-2020 under drought-stressed (DS) and nonstressed (NS) conditions. Data were collected on KY; oil content (OC); oil yield (OY); protein content; palmitic, stearic, oleic, and linoleic acid contents; haulm yield (HY); and fodder quality parameters such as the contents of dry matter, ash, nitrogen (NC), neutral detergent fiber (NDFDM), acid detergent fiber (ADFDM), acid detergent lignin (ADLDM), in vitro digestibility, and metabolizable energy. Data were subjected to parametric and nonparametric statistical analyses. Combined analysis of variance revealed significant $(P<.05)$ genotype differences for all assessed traits. Genotype $\times$ water regime interaction effects were significant for KY, OC, ash, NC, NDFDM, and ADLDM. Kernel yield positively and significantly $(P<.05)$ correlated with OY $(r=.99)$, LAC $(r=.13)$, ash $(r=.32)$, and NDFDM $(r=.54)$ under DS condition. Haulm yield was positively and significantly $(P<.05)$ correlated with OC $(r=.24), \operatorname{NDFDM}(r=.19)$, $\operatorname{ADFDM}(r=.18)$, and ADLDM $(r=.17)$ under DS condition. The study identified four genotypes with high kernel and haulm yields, and six genotypes with high oleic acid content. Further, 10 genotypes were selected with relatively better drought tolerance. The selected genotypes are recommended for further breeding and variety release adapted to drought conditions.
\end{abstract}

\section{1 | INTRODUCTION}

Abbreviations: ADFDM, acid detergent fiber; ADLDM, acid detergent lignin; DM, dry matter; DS, drought-stressed; HY, haulm yield; KY, kernel yield; LAC, linoleic acid content; ME, metabolizable energy; NC, nitrogen content; NDFDM, neutral detergent fiber; NS, nonstressed; OAC, oleic acid content; OC, oil content; OY, oil yield; PAC, palmitic acid content; TPC, total protein content; SAC, stearic acid content; STI, stress tolerance index.
Groundnut (Arachis hypogaea $\mathrm{L}$; $2 \mathrm{n}=4 \mathrm{x}=40$ ) is an important oilseed crop with multiple uses in the food and feed sectors. It is cultivated in diverse agro-ecologies including the semi-arid tropics and subtropical regions globally. Groundnut is mainly cultivated as a source of vegetable oil for local, regional and international markets (Ojiewo et al., 2020). 
Further, groundnut kernels are eaten raw, roasted, boiled, or processed into groundnut butter (Janila et al., 2013). The oil content of groundnut kernels varies from 45 to $56 \%$ (Bishi et al., 2013; Sarvamangala et al., 2011; Yol et al., 2017). Groundnut oil is one of the premium cooking oils for its stability at high temperatures and higher smoke point conditions compared with soybean (Glycine max) and rapeseed (Brassica napus) oils (Che \& Min, 2007). Groundnut kernels contain macro-and micronutrients such as calcium $\left(920 \mathrm{mg} \mathrm{kg}^{-1}\right)$, magnesium $\left(1,690 \mathrm{~m} \mathrm{~kg}^{-1}\right)$, potassium $\left(7,054 \mathrm{mg} \mathrm{kg}^{-1}\right)$, iron (46 mg kg${ }^{-1}$ ) and zinc (33 $\mathrm{mg} \mathrm{kg}^{-1}$; Nigam, 2014). The kernels are also rich in vitamins (e.g., vitamins $\mathrm{E}, \mathrm{K}$, and B) and protein ( 25\%; Janila et al., 2014; Sarvamangala et al., 2011). The main fatty acids present in groundnut are oleic acid (80\%), linoleic acid ( 40\%) and palmitic acid (5-10\%; Bishi et al., 2013). It also consists of minor fatty acids such as stearic, arachidic, eicosenoic, behenic, lignoceric, and gadoleic acids each accounting between 1 and 3\% of the total fatty acid (Andersen et al., 1998). Groundnut genotypes with oleic acid content $\geq 78 \%$ are referred to as high oleic genotypes and possess oil with longer shelf life (Deshmukh et al., 2020; Janila, Radhakrishnan et al., 2018). The high auto-oxidative stability nature of oleic acid is a key factor attributing to the extended shelf life of the oil (Nawade et al., 2018). Groundnut oil with high linoleic acid content is prone to oxidation which result in unpleasant odor and taste, and reduced shelf-life (Shasidhar et al., 2020). Therefore, high oleic acid/linoleic acid ratio is a desired quality parameter to enhance the shelf-life of groundnut oil. Developing groundnut genotypes with high oleic acid is a key breeding objective for human health, product quality and to access the lucrative market opportunities (Nawade et al., 2018).

Groundnut haulm serves as an important feed source for livestock in fresh or dry forms. This is essential in the croplivestock farming systems such as in Ethiopia and other arid and semi-arid regions where grazing lands are limited (Abady et al., 2019; Frimpong et al., 2017; Sabagh et al., 2019). Reportedly, the haulm contains protein ranging from 8 to $15 \%$, lipid (1-3\%), minerals (9-17\%) and carbohydrates (38-45\%; Janila et al., 2016). These attributes make groundnut haulm as a source of quality fodder to supplementing the diet of livestock. Key quality parameters of the haulm include the contents of nitrogen, in vitro organic matter digestibility, and metabolized energy (Joshi et al., 2019). In vitro organic matter digestibility is the proportion of organic matter that is digested in the ruminant digestive tract. Metabolizable energy is the net energy available for animal growth or reproduction after fecal and urinary energy loss (Samireddypalle et al., 2017). Conversely, carbohydrate components such as high neutral detergent fiber, acid detergent fiber, and acid detergent lignin have negative effects on haulm quality due to their indigestibility (Samireddypalle et al., 2017). Neutral detergent fiber includes all cell wall components and acid detergent

\section{Core Ideas}

- Diverse groundnut germplasm collections are available and can be evaluated for drought.

- Strong correlations observed among haulm quality traits under drought-stressed and optimum conditions.

- The study identified genotypes with high kernel and haulm yields and drought tolerance.

fiber. Acid detergent fiber corresponds to cellulose and lignin contents (Mertens, 2000).

Due to its multiple uses and relatively higher drought tolerance, groundnut is grown in the mixed crop-livestock production systems in sub-Saharan Africa and Asia mainly by small-holder farmers. These agro-ecosystems are droughtprone where land, water, and natural pastures are becoming increasingly scarce (Abady et al., 2019). Drought stress caused by low precipitation is the leading cause of the decline of natural grazing lands resulting in high livestock mortality. For example, in Tanzania livestock mortality, herd value and income losses attributed to drought accounted for 5, 4, and 31\%, respectively (Ahmed et al., 2019). Similarly, small-holder farmers in some parts of Ghana reported chronic water shortages for both human and livestock due to drought (Ngcamu \& Chari, 2020). Drought stress occurring during the reproductive growth stage is the most devastating that can lead to a yield loss reaching up to 33\% (Carvalho et al., 2017; Pereira et al., 2016). Therefore, it is an overriding consideration to develop and deploy dual-purpose groundnut cultivars with high kernel and haulm yields and associated quality parameters with drought tolerance. In the past there was no dedicated groundnut breeding program that aimed at breeding genotypes with high kernel and haulm yields with quality attributes under drought stress environments.

Groundnut exhibits extensive phenotypic and genotypic diversity (Pandey et al., 2012; Ren et al., 2014; Upadhyaya et al., 2005; Zheng et al., 2018). Moreover, marked variation for drought tolerance has been reported in groundnut germplasm collections (Falke et al., 2019; Frimpong et al., 2019; Hamidou et al., 2012). These present opportunities to develop fit-for-purpose genotypes for food and feed with drought tolerance. The International Crops Research Institute for the Semi-Arid Tropics (ICRISAT) in India maintains the world's largest collection of groundnut germplasm which are essential sources of genetic variation with desirable attributes for breeding. The groundnut genetic resources at ICRISAT mainly comprise of the Spanish (subspecies fastigiata) and Virginia (subspecies hypogaea) market types. Many of these genotypes possess desirable agronomic traits which can be exploited for designing new groundnut cultivars (Singh \& Nigam, 2016). Therefore, the diverse groundnut 
germplasm collections can be sourced and rigorously evaluated for drought tolerance and kernel and fodder yield and associated quality traits to select unique genotypes for breeding. In light of the above background, the objective of this study was to determine the response of diverse groundnut genotypes for drought tolerance, kernel and fodder yield, and quality for direct production or breeding.

\section{2 | MATERIAL AND METHODS}

\section{1 | Plant materials, site description, and experiment design}

Hundred groundnut genotypes acquired from ICRISAT in Patancheru, India were used for the study. The list of the genotypes with pedigree information are shown in Supplemental Table S1. Of these genotypes, 70 belonged to the subsp. fastigiata var. vulgaris and 30 to the subsp. hypogaea var. hypogaea. The genotypes were selected based on desirable traits including drought tolerance, resistance to foliar diseases such late leaf spot and rust, high oil and oleic acid contents, and being early-to-medium maturing. The genotypes were evaluated under drought-stressed (DS) and nonstressed (NS) conditions at ICRISAT (latitude, $17.51^{\circ} \mathrm{N}$, longitude, $78.27^{\circ} \mathrm{E}$ and altitude $545 \mathrm{~m}$ ) during the 2018-2019 and 2019-2020 postrainy cropping seasons using a 10-by-10 $\alpha$-lattice design with two replications. Seed of each genotype were sown in four, 4-m-long rows with $30 \mathrm{~cm}$ between rows and $10 \mathrm{~cm}$ between plants. The field was maintained with regular irrigation until flowering for NS and DS treatments, after which irrigation was withdrawn for the DS treatment to induce moisture stress. For the NS treatment, sufficient irrigation was supplied until physiological maturity. Other agronomic practices were carried out following the standard guideline for groundnut production (Janila, Manohar et al., 2018).

\section{2 | Data collection}

Data were collected on kernel and haulm yields (KY and HY, respectively) from each plot and converted to tons per hectare $\left(\mathrm{t} \mathrm{ha}{ }^{-1}\right)$. Oil yield in $\mathrm{t} \mathrm{ha}^{-1}(\mathrm{OY}=$ oil content in $\%$ times kernel yield in $\mathrm{tha}^{-1}$ ), the contents of total oil (OC), total protein (TPC), palmitic acid (PAC), stearic acid (SAC), oleic acid (OAC), and linoleic acid (LAC) contents of the kernels were estimated using a Near Infrared Spectroscopy (NIRS; XDS monochromator, FOSS Analytical AB, Hillerød, Sweden; Deshmukh et al., 2020). Data on dry HY was collected and expressed in $\mathrm{t} \mathrm{ha}^{-1}$. Briefly, the haulm samples were collected at physiological maturity by cutting from aboveground at the soil surface followed by oven drying at $70{ }^{\circ} \mathrm{C}$ for $3 \mathrm{~d}$. Subsequently, haulm weights were recorded, and the samples were ground into powder for NIRS analysis. Haulm fodder quality parameters including the contents of dry matter (DM), ash, neutral detergent fiber (NDFDM), acid detergent fiber (ADFDM), acid detergent lignin (ADLDM), and in vitro digestibility (IVOMD), and metabolizable energy (ME) were estimated using a NIRS using a FOSS Forage Analyzer 5000 with software package WinISI II (Kadim et al., 2005 ). Nitrogen was determined using the Kjeldahl method (Da Silva et al., 2016).

\section{3 | Data analysis}

Data was subjected to analysis of variance using SAS version 9.3 Software. Differences between treatment means were determined using the least significant difference (LSD) test at $5 \%$ significance level. Heritability in a broad sense $\left(\mathrm{H}^{2}\right)$ was calculated according to Hill et al. (2012) using the following formulae: $H^{2}=V_{g} /\left[V_{g}+V_{g e} / e+V_{e} / r e\right]$ where $\mathrm{V}_{\mathrm{g}}$ is genetic variance, $V_{g e}$ is genotype $\times$ environment interaction variance, $V_{e}$ is error variance, $e$ is number of environments, and $r$ number of replications. Stress tolerance index (STI) was calculated to select high kernel and haulm yielding genotypes under DS and NS conditions using the following formula (Fernandez, 1992): STI $=\left(Y_{p} Y_{s}\right) /\left(Y_{\bar{p}}\right)^{2}$ where $Y_{s}$ is yield of genotypes under DS condition; $Y_{p}$ is yield of genotypes under NS condition, and $Y_{\bar{p}}$ is mean yield of test genotypes under NS condition. Pearson correlation coefficients was performed using SAS software to determine the level of association among the assessed traits. Principal component analysis was performed using JMP software. Principal component biplots were constructed to determine association among traits and groundnut genotypes to aid simultaneous selection of genotypes with multiple traits. Hierarchical cluster analysis based on Ward method was computed using JMP Trail 15 version software to determine genetic groupings of the test genotypes. For subspecies comparison, the mean values for the two subspecies were statistically compared using a t-test at 5\% level of significance. Boxplots were constructed using the ggpubr package in $\mathrm{R}$ version 4.0 ( $\mathrm{R}$ Core Team, 2020).

\section{3 | RESULTS}

\section{1 | Effects of genotypes, water regimes, and seasons on KY, HY, OC, and haulm quality parameters}

Combined analysis of variance revealed highly significant $(p<.05)$ genotype differences for kernel yield, OC, and fatty acids contents (Table 1). Significant genotype by water regime interaction effect was recorded for kernel yield and OC. 
TA B L E 1 Mean squares and significant test among 100 groundnut genotypes evaluated for kernel yield (KY), oil content (OC), fatty acid compositions, and haulm yield (HY) and quality attributes across 2018-2019 and 2019-2020 postrainy seasons under drought-stressed and nonstressed conditions

\begin{tabular}{|c|c|c|c|c|c|c|c|c|c|c|c|c|}
\hline \multirow[b]{2}{*}{ Source of variation } & \multirow[b]{2}{*}{$d f$} & \multicolumn{11}{|c|}{ Kernel yield, oil content, and fatty acid compositions } \\
\hline & & $\overline{\mathrm{KY}}$ & \multicolumn{2}{|l|}{ OC } & \multicolumn{2}{|l|}{$\mathbf{O Y}^{\mathrm{a}}$} & TPC & \multicolumn{2}{|c|}{ PAC } & SAC & \multirow{2}{*}{ OAC } & LAC \\
\hline Year $(\mathrm{Y})$ & 1 & $74.55^{* *}$ & \multicolumn{2}{|c|}{$373.46^{* *}$} & \multicolumn{2}{|c|}{$14.20^{* *}$} & $350.05^{* *}$ & \multicolumn{2}{|c|}{$0.041 \mathrm{~ns}$} & $85.02 * *$ & & $51.03 \mathrm{~ns}$ \\
\hline Genotype (G) & 99 & $0.58^{* *}$ & \multicolumn{2}{|c|}{$21.02^{* *}$} & \multicolumn{2}{|c|}{$0.14^{* *} *$} & $10.68^{* *}$ & \multicolumn{2}{|c|}{$20.11^{* * *}$} & $0.61 * *$ & $774.97 * *$ & $547.64 * *$ \\
\hline $\operatorname{Rep}(\mathrm{Y})$ & 2 & $2.01 * *$ & \multicolumn{2}{|c|}{$82.27 * *$} & \multicolumn{2}{|c|}{$0.69 * *$} & $114.23 * *$ & 5.6 & & $6.34 * *$ & $60.65 \mathrm{~ns}$ & $266.49 * *$ \\
\hline $\mathrm{G} \times \mathrm{Y}$ & 99 & $0.30^{* *}$ & 5.85 & & 0.07 & $7 * *$ & $6.06^{*}$ & 1.4 & & $0.16 \mathrm{~ns}$ & $51.41^{*}$ & $36.01 *$ \\
\hline $\mathrm{G} \times \mathrm{WR} \times \mathrm{Y}$ & 100 & $0.44^{* *}$ & 11.36 & & 0.17 & & $8.10^{* *}$ & & $5 \mathrm{~ns}$ & 0.30 ** & $47.25^{*}$ & $37.31 *$ \\
\hline Error & 362 & 0.15 & 4.52 & & 0.03 & & 3.81 & 0.9 & & 0.15 & 35.68 & 25.45 \\
\hline & & Haulm yielc & d and quali & ty pa & aramete & & & & & & & \\
\hline Genotype (G) & 99 & $6.11 * *$ & $0.14^{*}$ & & $2.93 * *$ & $0.06^{* *}$ & & $00^{*}$ & $5.49^{*}$ & $0.32 *$ & $3.33^{* *} *$ & $0.09 * *$ \\
\hline $\operatorname{Rep}(\mathrm{Y})$ & 2 & $47.99 * *$ & $0.79^{*}$ & & $3.07 *$ & $0.10^{*}$ & & $14 \mathrm{~ns}$ & $30.78 *$ & $1.01^{*}$ & $19.33^{* *}$ & $0.65^{* *}$ \\
\hline Block $(Y \times$ Rep $)$ & 36 & $2.62 *$ & $0.05 \mathrm{~ns}$ & & $2.03 \mathrm{~ns}$ & $0.03 \mathrm{~ns}$ & & $01 \mathrm{~ns}$ & $5.09 \mathrm{~ns}$ & $0.28 \mathrm{~ns}$ & $2.23^{*}$ & $0.06^{*}$ \\
\hline $\mathrm{G} \times \mathrm{WR}$ & 99 & $1.62 \mathrm{~ns}$ & $0.08 \mathrm{~ns}$ & & $2.50 *$ & $0.04 *$ & & $69 *$ & $4.53 \mathrm{~ns}$ & $0.27^{*}$ & $1.85 \mathrm{~ns}$ & $0.05 \mathrm{~ns}$ \\
\hline $\mathrm{G} \times \mathrm{Y}$ & 99 & $1.68 \mathrm{~ns}$ & $0.10 \mathrm{~ns}$ & & $2.13^{*}$ & $0.03 \mathrm{~ns}$ & & $42 *$ & $4.07 \mathrm{~ns}$ & $0.29 *$ & $1.86 \mathrm{~ns}$ & $0.05 \mathrm{~ns}$ \\
\hline $\mathrm{G} \times \mathrm{WR} \times \mathrm{Y}$ & 100 & $5.17 * *$ & $0.10 \mathrm{~ns}$ & & $2.68^{* *}$ & $0.02 \mathrm{~ns}$ & & $33 \mathrm{~ns}$ & $4.92 *$ & $0.50 * *$ & $2.17^{*}$ & $0.06^{*}$ \\
\hline Error & 362 & 1.52 & 0.09 & & 1.54 & 0.02 & 4 & & 3.54 & 0.2 & 1.52 & 0.2 \\
\hline
\end{tabular}

${ }^{a} \mathrm{OY}$, oil yield; TPC, total protein content; PAC, palmitic acid content; SAC, stearic acid content; OAC, oleic acid content; LAC, linoleic acid content; HY, haulm yield; DM, dry matter; NDFDM, Neutral detergent fiber; ADFDM, acid detergent fiber; ADLDM, acid detergent lignin; IVOMD, in vitro organic matter digestibility; ME, metabolizable energy.

*Significant at the .05 probability level;

**Significant at the .01 probability level; ns, nonsignificant.

Genotype $\times$ year interaction effect was significant for all traits except SAC, whereas genotype $\times$ water regime $\times$ year interaction effect was significant for all traits except PAC. Analysis of variance revealed highly significant $(p<.05)$ genotype differences for HY and quality parameters. Also, significant genotype $\times$ water regime interaction effect was noted for nitrogen, NDFDM, and ADLDM. Genotype $\times$ year interaction effect was significant for ash, NDFDM, and ADLDM, whereas genotype $\times$ water regime $\times$ year interaction effect was significant for HY, ash, ADLDM, IVODM, and ME.

\section{2 | Performance of groundnut genotypes for $\mathrm{KY}, \mathrm{OC}$, and fatty acids composition under NS and DS conditions}

Mean performance of the assessed groundnut genotypes for (KY, OC, and fatty acid composition under DS and NS conditions in the 2018-2019 and 2019-2020 postrainy seasons are presented in Table 2 and Supplemental Table S2. Highly significant $(p<.001)$ genotype differences were recorded for KY under NS and DS conditions. Under DS condition, the highest KY was recorded for ICGV $06040\left(1.2 \mathrm{t} \mathrm{ha}^{-1}\right)$, ICGV $7222\left(1.17 \mathrm{t} \mathrm{ha}^{-1}\right)$, ICGV $01260\left(1.14 \mathrm{t} \mathrm{ha}^{-1}\right)$, ICGV 10178 (1.11 $\left.\mathrm{t} \mathrm{ha}^{-1}\right)$, ICGV $06175\left(1.1 \mathrm{t} \mathrm{ha}^{-1}\right)$, and ICGV 10373 $\left(1.07\right.$ tha $\left.^{-1}\right)$. Genotypes ICGV 10143, ICGV 7222, ICGV 03042, ICGV 06039, ICGV 98412, ICGV 14001, and ICGV 06040 were high-yielding $\left(>2 \mathrm{tha}^{-1}\right)$ under NS condition.

For OC, highly significant $(p<.001)$ differences were recorded among the test genotypes under both conditions. Under DS condition, the highest OC was recorded for ICGV 10379 (53.9\%), ICGV 00064 (52.8\%), ICGV 86699 (52.07\%), ICGV 95111 (51.97\%), and ICGV 96266 (51.14\%). Genotypes ICGV 98385, ICGV O1279, GPBD 4, and ICGV 00246 recorded high OC of $>50 \%$ under NS condition. Highly significant $(p<.001)$ genotype differences were recorded for OY under both conditions. Under DS condition, the highest OY was recorded for ICGV $6040\left(0.58 \mathrm{t} \mathrm{ha}^{-1}\right)$, ICGV $10178\left(0.54 \mathrm{t} \mathrm{ha}^{-1}\right)$, ICGV $01260\left(0.54 \mathrm{t} \mathrm{ha}^{-1}\right)$, ICGV 7222 $\left(0.53 \mathrm{t} \mathrm{ha}^{-1}\right)$, ICGV $10373\left(0.52 \mathrm{t} \mathrm{ha}^{-1}\right)$, and ICGV 06175 


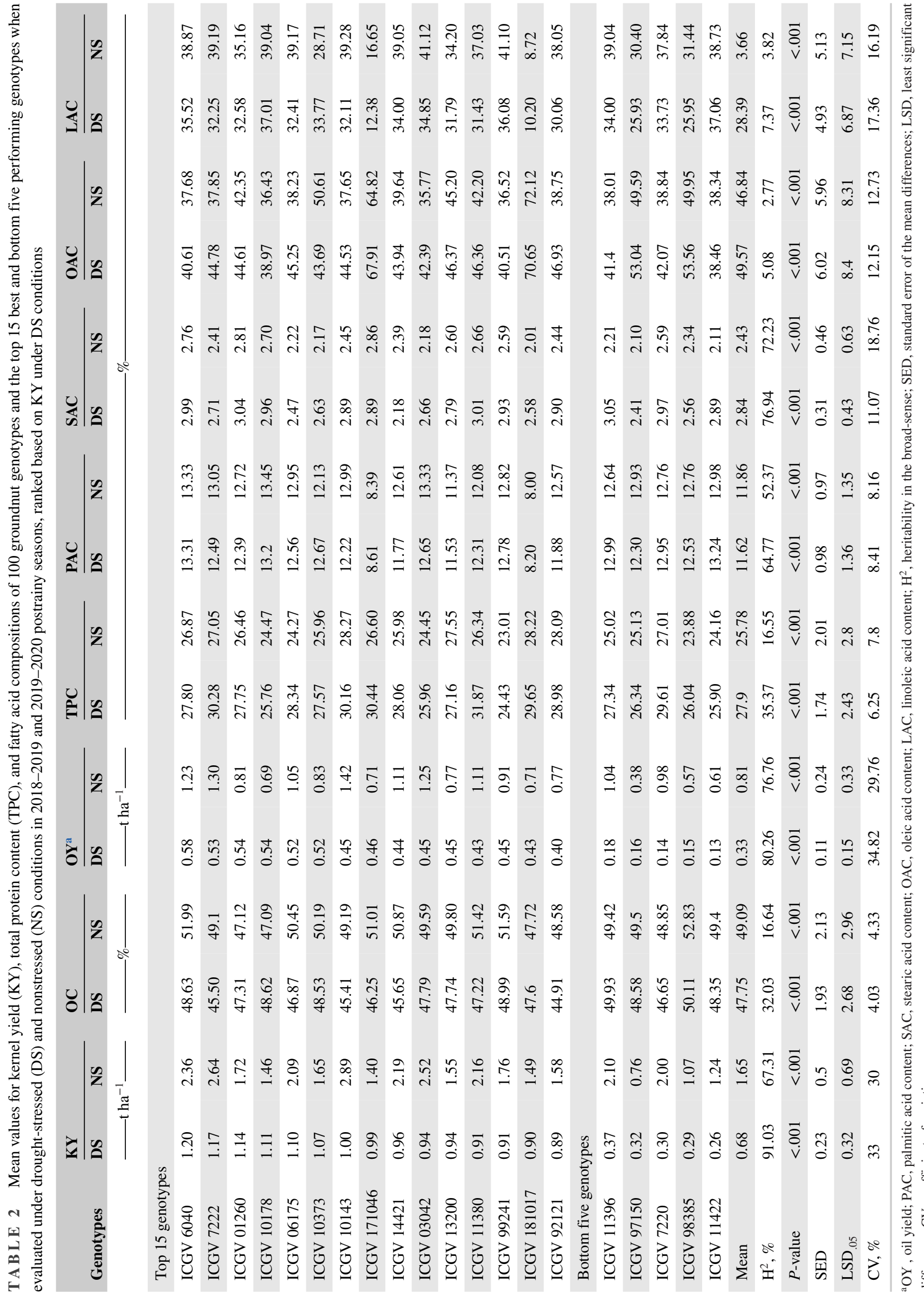


(0.52 $\left.\mathrm{t} \mathrm{ha}^{-1}\right)$. Genotypes ICGV 10143, ICGV 06039, ICGV 7222, ICGV 03042, ICGV 14001, and ICGV 06040 recorded high OY $\left(>1.2 \mathrm{t} \mathrm{ha}^{-1}\right)$ under NS condition. Significantly higher TPC (>30\%) was recorded in genotypes ICGV 11380 , ICGV 171007, ICGV 181490, and ICGV 171046 under DS condition, whereas genotypes ICGV 06146, ICGV 13219, ICGV 14030, and ICGV 10143 recorded high TPC (>28\%) under NS condition.

Palmitic acid content differed significantly among the assessed groundnut genotypes under both conditions. Under DS condition, the highest PAC was recorded for ICGV 00187 (13.76\%), ICGV 13254 (13.54\%), ICGV 00213 (13.39\%), ICGV 06040 (13.31\%), and ICGV 96165 (13.29\%). Under NS condition, genotypes ICGV 00187, ICGV 96165, and ICGV 94118 had the highest PAC (>14\%). For SAC, the highest value was recorded for ICGV 00213 (3.66\%), ICGV 98412 (3.58\%), ICGV 96174 (3.54\%), and ICGV 00187 (3.5\%) under DS condition, whereas genotypes ICGV 94118, ICGV 98412, GG 20, and ICGV 13254 recorded high concentrations $(>3 \%)$ under NS condition. Highly significant $(p<.001)$ genotype differences were observed for OAC under both conditions. The highest OAC was recorded for ICGV 181026 (71.64\%), ICGV 15019 (71.16\%), ICGV 181017 (70.65\%), ICGV 181063 (69.68\%), and ICGV 16667 (68.89\%) under DS condition, whereas ICGV 181026, ICGV 181017, ICGV 171027, ICGV 16688, and ICGV 15074 recorded high OAC ( $>69 \%)$ under NS condition. Highly significant $(p<.001)$ genotype differences were observed for linoleic acid. Under DS condition, genotypes ICGV 181026, ICGV 181017, ICGV 15019, ICGV 181063, ICGV 16667, ICGV 171046, and ICGV 171026 expressed low LAC $(<13 \%)$ under NS condition. High $\mathrm{H}^{2}$ values $(>70 \%)$ were recorded for $\mathrm{KY}, \mathrm{OY}$, and SAC under both water conditions. Low to medium $\mathrm{H}^{2}$ values were observed for OAC, LAC, OC, TPC, and PAC under both moisture conditions (Table 2).

\section{3 | Performance of groundnut genotypes for $\mathrm{HY}$ and quality parameters}

Mean performance of groundnut genotypes for HY and quality parameters under DS and NS conditions are presented in Table 3 and Supplemental Table S3. Significant genotype differences were observed among the test genotypes for HY under both conditions. Under DS condition, the highest HY was recorded for ICGV 01260 (7.79 $\mathrm{t} \mathrm{ha}^{-1}$ ), ICGV 96165 (7.29 $\left.\mathrm{t} \mathrm{ha}^{-1}\right)$, ICGV 171027(6.88 $\left.\mathrm{tha}^{-1}\right)$, ICGV 96266 (6.71 $\left.\mathrm{t} \mathrm{ha}^{-1}\right)$, and ICGV $14232\left(6.51 \mathrm{t} \mathrm{ha}^{-1}\right)$, whereas genotypes ICGV 01491, ICGV 181006, ICGV 00211, and ICGV 97115 recorded high HY $\left(>8.5 \mathrm{t} \mathrm{ha}^{-1}\right)$ under NS condition.

Higher $\mathrm{H}^{2}$ value $(>60 \%)$ was recorded for $\mathrm{HY}$ and ME under DS condition and nitrogen content (NC) under NS condition, whereas lower $\mathrm{H}^{2}$ value was recorded for ash con- tent, DM, ADFDM, and ADLDM under DS condition. Under NS condition, higher NCs were recorded for genotypes ICGV 93162 (2.94\%), ICGV 171007 (2.91\%), and ICGV 99019 (2.84\%), whereas genotypes ICGV 01491, ICGV 171007, ICGV 171039, and ICGV 05057 recorded high NC of $>3 \%$ under DS condition. Significantly $(p<.001)$ higher ash contents were recorded for ICGV 86015 (18.36\%), ICGV 96165 (17.18\%), ICGV 14232 (17.15\%), ICGV 14421 (16.27\%), and ICGV 7220 (15.95\%) under DS condition. Highly significant $(p<.001)$ differences were recorded among groundnut genotypes for NDFDM under DS condition. Under DS condition, the lowest NDFDM was recoded for genotypes ICGV 86015 (32.03\%), ICGV 96165 (34.29\%), ICGV 14232 (37.04\%), and ICGV 00187 (37.23\%). Significant $(p<.05)$ genotype differences were observed for ADFDM and ADLDM under DS condition. The highest ADFDM was noted for ICGV 03043 (31.93\%), ICGV 00211 (31.4\%), ICGV 171013 (31.3\%), and ICGV 16667 (31.24\%), whereas genotypes ICGV 171039, ICGV 181033, ICGV 13200, ICGV 14030, and ICGV 13219 recorded low ADFDM of $<27 \%$ under DS. High ADLDM were recorded for ICGV 181489 (5.56\%), ICGV 16667 (5.54\%), ICGV 00211 (5.46\%), ICGV 03043 (5.43\%), and ICGV 171013 (5.43\%), whereas genotypes ICGV 171039 (4.21\%), ICGV 14030 (4.24\%), ICGV 181033 (4.36\%), ICGV $171046(4.38 \%)$ and ICGV $13219(4.39 \%)$ recorded low ADLDM of $<5 \%$ under DS condition. Groundnut genotypes differed significantly $(P<.05)$ for IVODM under DS condition. The highest IVODM was recorded for GG 20 (63.52\%), ICGV 171007 (63.43\%), ICGV 14030 (63.41\%), ICGV 86031 (63.23\%), and ICGV 13219 (63.07\%) under DS condition. Significant genotype differences were observed among the genotypes for ME under both conditions. Under DS condition, high ME values were recorded for GG 20 (63.52\%), ICGV 171007 (63.43\%), ICGV 14030 (63.41\%), CGV 86031(63.23\%), and CGV 13219 (63.07\%).

\section{4 | Comparison of groundnut subspecies for KY, HY, and quality parameters}

Comparison of groundnut subspecies (i.e., fastigiata and hypogaea) for $\mathrm{KY}$ and $\mathrm{HY}$ and kernel and fodder quality under DS and NS conditions are presented in Figure 1 and Supplemental Figure S1. Significant $(p<.05)$ difference was recorded between the two subspecies for KY with fastigiata recoding higher KY. Under both conditions, significant differences were observed between the two subspecies for OC. Subspecies hypogaea recorded high mean OC of $48.87 \%$ and $49.75 \%$ under DS and NS conditions compared to subspecies fastigiata. There were nonsignificant differences between the two subspecies for TPC, PAC, SAC, OAC, and LAC under both conditions. Significantly $(p<.001)$ higher HY was recorded for subspecies hypogaea 


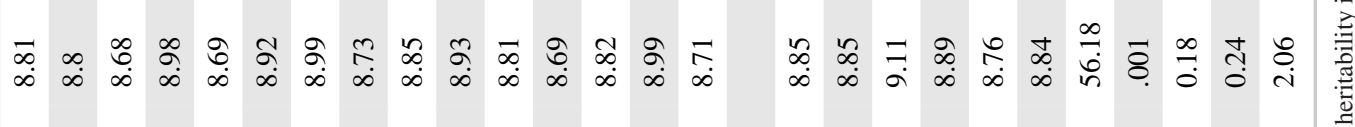

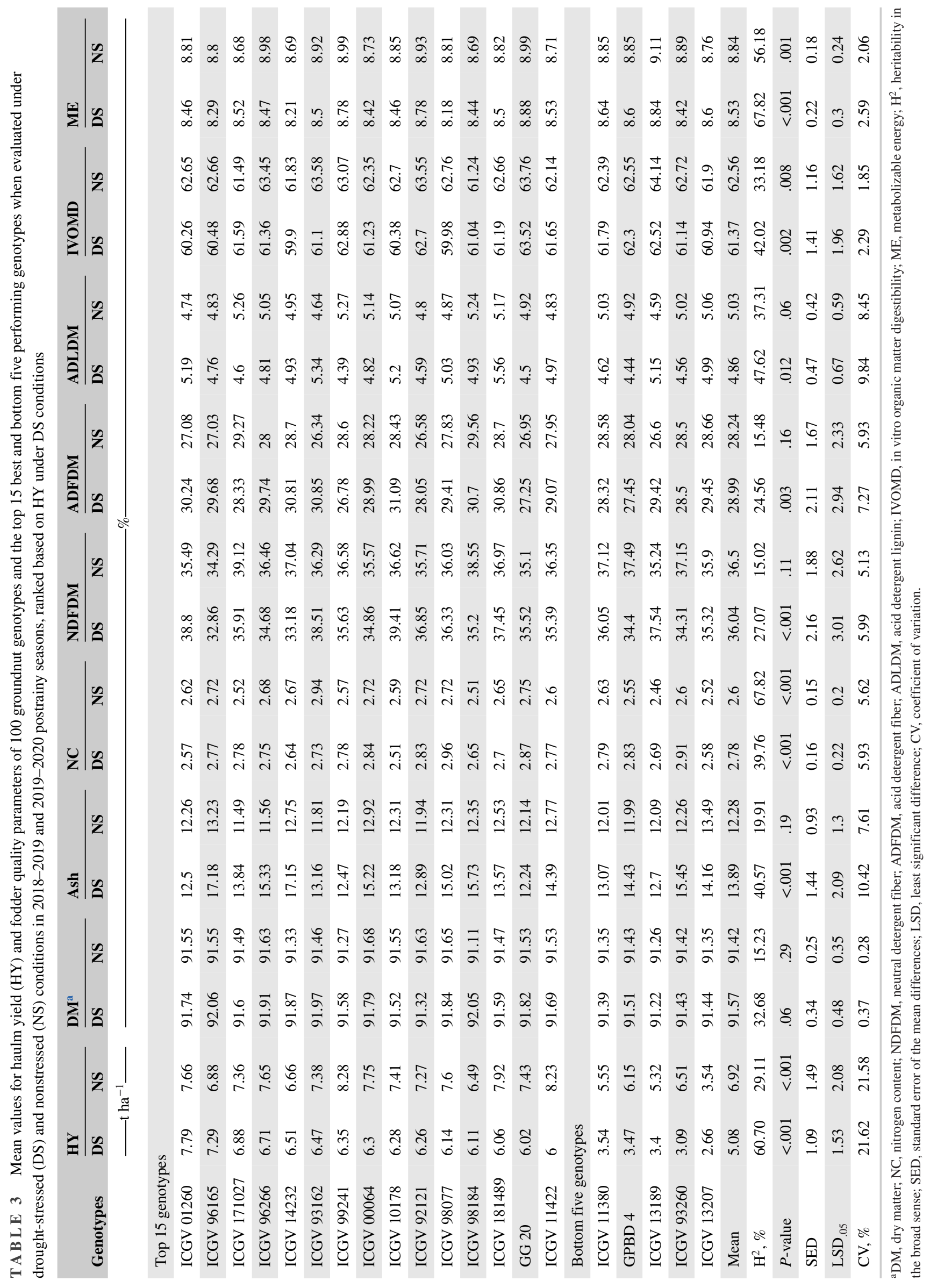



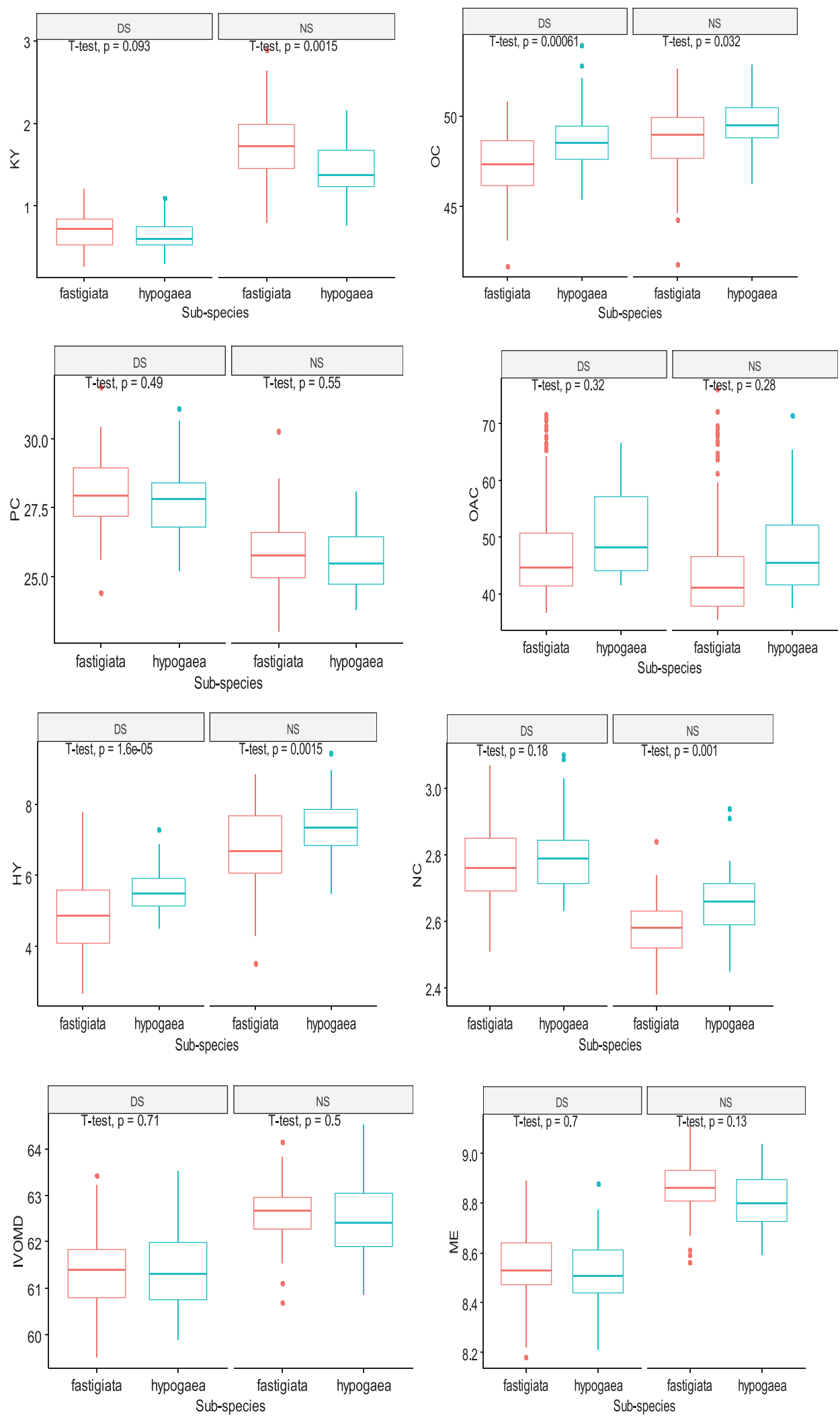

F I G U R E 1 Mean response of groundnut subspecies for kernel and haulm yields, and kernel and fodder quality parameters under drought-stressed (DS) and nonstressed (NS) conditions evaluated during 2018-2019 and 2019-2020 postrainy seasons at the International Crops Research Institute for the Semi-Arid Tropics, India. KY, kernel yield; OC, oil content; PC, protein content; OAC, oleic acid content; HY, haulm yield; NC, nitrogen content; IVOMD, in vitro organic matter digestibility; ME, metabolizable energy 
under DS (mean $\left.=5.64 \mathrm{t} \mathrm{ha}^{-1}\right)$ and NS (mean $\left.=7.44 \mathrm{t} \mathrm{ha}^{-1}\right)$ compared to subspecies fastigiata. Subspecies hypogaea recorded significantly higher DM content of $91.77 \%$ than subspecies fastigiata under DS condition. Ash content showed nonsignificant differences between the two Arachis subspecies under both conditions. Under NS condition, significant $(p<.05)$ differences were recorded between the two subspecies for NC with subspecies hypogaea recording higher mean NC of $2.80 \%$. For NDFDM and ADFDM, nonsignificant subspecies differences in mean values were observed under both water conditions. Subspecies hypogaea had high mean value for ADLDM (5.12\%) compared to lower value of $4.99 \%$ for subspecies fastigiata under NS condition. For IVODM and ME, nonsignificant differences were detected between the two subspecies under both water conditions. Except for OAC and PAC, significant $(p<.05)$ difference was recorded between DS and NS treatments (Supplemental Figure S2). Higher mean values were recorded for TPC, SAC, $\mathrm{DM}$, ash, and NC under DS than NS condition.

\section{5 | Drought stress tolerance}

Stress tolerance index (STI) of the assessed groundnut genotypes is presented in Table 4 . The STI was used to identify genotypes that can provide high yields under both stressed and nonstressed conditions (Fernandez, 1992). Higher STI values for KY were recorded for ICGV $7222(\mathrm{STI}=1.14)$, ICGV 10143 (1.06), ICGV 6040 (1.04), ICGV 03042 (0.87), and ICGV 06175 (0.85). For HY, groundnut genotypes such as ICGV 01260, ICGV 99241, ICGV 96266, ICGV 171027, and ICGV 01491 recorded higher STI values of $>1$ indicating the stable performance of the genotypes under both conditions. Genotypes ICGV 7222, ICGV 10143, ICGV 01260, and ICGV 99241 are drought tolerant and ICGV 6040 is early maturing genotypes developed by ICRISAT in India (Table S1).

\section{6 | Relationships between KY and HY and oil and haulm quality parameters under NS and DS conditions}

Pearson correlation coefficients showing relationships among $\mathrm{KY}$ and $\mathrm{HY}$ and kernel and haulm quality parameters among the 100 groundnut genotypes evaluated under DS and NS conditions are presented in Tables 5. Under DS condition, KY was positively correlated $(p<.001)$ with OY $(r=.99)$ and negatively and significantly correlated $(P<.05)$ with SAC $(r=.63)$. Oil content exhibited positive and significant correlation with OY $(r=.12)$ and OAC $(r=.12)$. Kernel yield was poorly and positively correlated with $\mathrm{HY}(r=.14)$, but negatively correlated with DM (.76), NC (.53), IVODM (.37), and
ME (.33). Contrastingly, KY positively and significantly correlated with ash content $(r=.32)$, NDFDM $(r=.54)$, ADFDM $(r=.18)$, and ADLDM $(r=.46)$. Haulm yield was positively correlated with OY $(r=.15)$ and negatively correlated with $\mathrm{NC}(r=.20)$, IVODM $(r=.13)$, and ME (0.12), and positive correlation with NDFDM $(r=0.19)$, ADFDM $(r=.18)$, and $\operatorname{ADLDM}(r=.17)$.

Under NS condition, KY exhibited positive correlations with OY ( $r=.98)$, protein content $(r=.11)$ and LAC $(r=.15)$. Oil content exhibited low and positive correlation with OY $(r=.14)$, SAC (.19) and LAC (.18). Haulm yield exhibited positive correlation with OC (.31), DM $(r=.54)$, ash content $(r=.4)$, NC $(r=.4)$, ME $(r=.4)$, and IVODM $(r=.43)$. Positive correlations were recorded between NC and IVODM (.67), NC and ME (.51), and IVODM and ME (.94). Positive correlations were observed between NC and IVODM (.72), $\mathrm{NC}$ and ME (.56), and IVODM and ME (.95). Positive correlations were recoded between neutral detergent fiber and $\operatorname{ADFDM}(r=.62)$, NDFDM and ADLDM $(r=.84)$, and $\operatorname{ADFDM}$ and $\operatorname{ADLDM}(r=.79)$. Positive correlations were observed between NDFDM and ADFDM $(r=.5)$, NDFDM and $\operatorname{ADLDM}(r=.5)$, and ADFDM and $\operatorname{ADLDM}(r=.85)$.

\section{7 | Principal component and biplot analyses}

Principal component analysis for the assessed traits among 100 groundnut genotypes revealed five and six principal components (PCs) with Eigenvalues greater than one under DS and NS condition, respectively. The principal component accounted for $79.35 \%$ and $82.54 \%$ of the total phenotypic variation under DS and NS conditions, respectively (Table 6). Under DS condition, PC1 positively correlated with ADFDM, ADLDM, and NDFDM and negatively correlated with IVODM and ME which accounted for $25.71 \%$ of total variation. Oleic acid content positively correlated with PC2, whereas PAC, LAC, and SAC negatively correlated with PC2 which accounted for $17.36 \%$ of total variation. Kernel yield, OY, and PC positively correlated with PC3 which accounted for $14.08 \%$ of total variation. Oil content and HY positively correlated with PC4 which accounted for $12 \%$ of total variation. Kernel yield and OY positively correlated with PC5 which accounted for $10.22 \%$ of total variation.

Under NS condition, NDFDM, ADFDM, and ADLDM positively correlated with PC1 whereas NC negatively correlated with PC1 which accounted for $24.38 \%$ of total variation. Kernel yield, OY, PAC, SAC, and LAC positively correlated with PC2, whereas OAC negatively correlated with PC2 which accounted for $21.68 \%$ of total variation. PC3 positively correlated with HY and negatively correlated with PC and ash content and both traits accounted for $13.02 \%$ of total variation. PC4 positively correlated with ME which 
T A B L E 4 Stress tolerance index (STI) of 100 groundnut genotypes based on kernel yield (KY) and haulm yield (HY) evaluated under drought-stressed and nonstressed conditions in 2018-2019 and 2019-2020 postrainy seasons

\begin{tabular}{|c|c|c|c|c|c|c|c|}
\hline \multirow[b]{2}{*}{ Number } & \multirow[b]{2}{*}{ Genotypes } & \multicolumn{2}{|l|}{ STI } & \multirow[b]{2}{*}{ Number } & \multirow[b]{2}{*}{ Genotypes } & \multicolumn{2}{|l|}{ STI } \\
\hline & & KY & HY & & & KY & HY \\
\hline 1 & ICGV 16667 & 0.27 & 0.91 & 51 & ICGV 00350 & 0.53 & 0.68 \\
\hline 2 & ICGV 93128 & 0.24 & 0.70 & 52 & ICGV 86590 & 0.42 & 0.80 \\
\hline 3 & ICGV 95066 & 0.41 & 0.77 & 53 & ICGV 02266 & 0.54 & 0.55 \\
\hline 4 & ICGV 96174 & 0.19 & 0.77 & 54 & ICGV 13189 & 0.58 & 0.38 \\
\hline 5 & ICGV 97087 & 0.32 & 1.01 & 55 & ICGV 13207 & 0.36 & 0.20 \\
\hline 6 & ICGV 98077 & 0.18 & 0.97 & 56 & ICGV 14421 & 0.77 & 0.49 \\
\hline 7 & ICGV 01279 & 0.33 & 0.83 & 57 & ICGV 13219 & 0.25 & 0.34 \\
\hline 8 & ICGV 03042 & 0.87 & 0.68 & 58 & GPBD 4 & 0.23 & 0.45 \\
\hline 9 & ICGV 06039 & 0.78 & 0.45 & 59 & ICGV 86031 & 0.27 & 0.45 \\
\hline 10 & ICGV 6040 & 1.04 & 0.73 & 60 & ICGV 16686 & 0.39 & 0.90 \\
\hline 11 & ICGV 07010 & 0.48 & 0.75 & 61 & ICGV 16005 & 0.30 & 0.68 \\
\hline 12 & ICGV 10143 & 1.06 & 0.60 & 62 & ICGV 171013 & 0.50 & 0.45 \\
\hline 13 & ICGV 11422 & 0.12 & 1.03 & 63 & ICGV 171026 & 0.35 & 0.81 \\
\hline 14 & ICGV 11396 & 0.29 & 0.86 & 64 & ICGV 171039 & 0.53 & 0.56 \\
\hline 15 & ICGV 11418 & 0.23 & 0.96 & 65 & ICGV 171046 & 0.51 & 0.54 \\
\hline 16 & ICGV 91223 & 0.23 & 0.53 & 66 & ICGV 181017 & 0.49 & 0.98 \\
\hline 17 & ICGV 94118 & 0.48 & 0.63 & 67 & ICGV 181063 & 0.15 & 0.88 \\
\hline 18 & ICGV 99019 & 0.55 & 0.92 & 68 & ICGV 98412 & 0.61 & 0.82 \\
\hline 19 & ICGV 00162 & 0.24 & 0.68 & 69 & ICGV 181489 & 0.15 & 1.00 \\
\hline 20 & ICGV 00211 & 0.46 & 0.84 & 70 & ICGV 181490 & 0.56 & 0.52 \\
\hline 21 & ICGV 00187 & 0.32 & 0.59 & 71 & ICGV 92054 & 0.22 & 0.85 \\
\hline 22 & ICGV 00213 & 0.37 & 0.64 & 72 & ICGV 93162 & 0.27 & 1.00 \\
\hline 23 & ICGV 06146 & 0.46 & 0.39 & 73 & ICGV 95111 & 0.32 & 0.96 \\
\hline 24 & ICGV 07120 & 0.41 & 0.75 & 74 & ICGV 96165 & 0.28 & 1.05 \\
\hline 25 & ICGV 10178 & 0.60 & 0.97 & 75 & ICGV 97115 & 0.25 & 0.90 \\
\hline 26 & ICGV 11380 & 0.72 & 0.41 & 76 & ICGV 98184 & 0.32 & 0.83 \\
\hline 27 & ICGV 14001 & 0.71 & 0.61 & 77 & ICGV 01491 & 0.21 & 1.06 \\
\hline 28 & ICGV 14030 & 0.41 & 0.43 & 78 & ICGV 03287 & 0.34 & 0.72 \\
\hline 29 & ICGV 86015 & 0.40 & 0.45 & 79 & ICGV 05057 & 0.27 & 0.70 \\
\hline 30 & ICGV 93260 & 0.48 & 0.42 & 80 & ICGV 06175 & 0.85 & 0.74 \\
\hline 31 & ICGV93261 & 0.49 & 0.41 & 81 & ICGV 00064 & 0.39 & 1.02 \\
\hline 32 & ICGV 92121 & 0.52 & 0.95 & 82 & ICGV 00246 & 0.31 & 0.75 \\
\hline 33 & ICGV 99241 & 0.59 & 1.10 & 83 & ICGV 97150 & 0.09 & 0.91 \\
\hline 34 & ICGV 00351 & 0.36 & 0.65 & 84 & ICGV 98385 & 0.11 & 0.94 \\
\hline 35 & ICGV 01260 & 0.72 & 1.25 & 85 & ICGV 96266 & 0.16 & 1.07 \\
\hline 36 & ICGV 01265 & 0.45 & 0.63 & 86 & ICGV 14224 & 0.52 & 0.88 \\
\hline 37 & ICGV 13200 & 0.54 & 0.37 & 87 & ICGV 14232 & 0.48 & 0.91 \\
\hline 38 & ICGV 7220 & 0.22 & 0.40 & 88 & ICGV 7262 & 0.35 & 0.65 \\
\hline 39 & ICGV 7222 & 1.14 & 0.53 & 89 & ICGV 7247 & 0.43 & 0.69 \\
\hline 40 & ICGV 13317 & 0.65 & 0.64 & 90 & ICGV 10371 & 0.33 & 0.69 \\
\hline 41 & ICGV 13254 & 0.40 & 0.80 & 91 & ICGV 10373 & 0.65 & 0.87 \\
\hline 42 & ICGV 181026 & 0.34 & 0.70 & 92 & ICGV 10379 & 0.54 & 0.96 \\
\hline 43 & ICGV 15073 & 0.36 & 0.77 & 93 & ICGV 15094 & 0.18 & 0.86 \\
\hline 44 & ICGV 15074 & 0.49 & 0.64 & 94 & ICGV 87846 & 0.46 & 0.89 \\
\hline
\end{tabular}


TA B L E 4 (Continued)

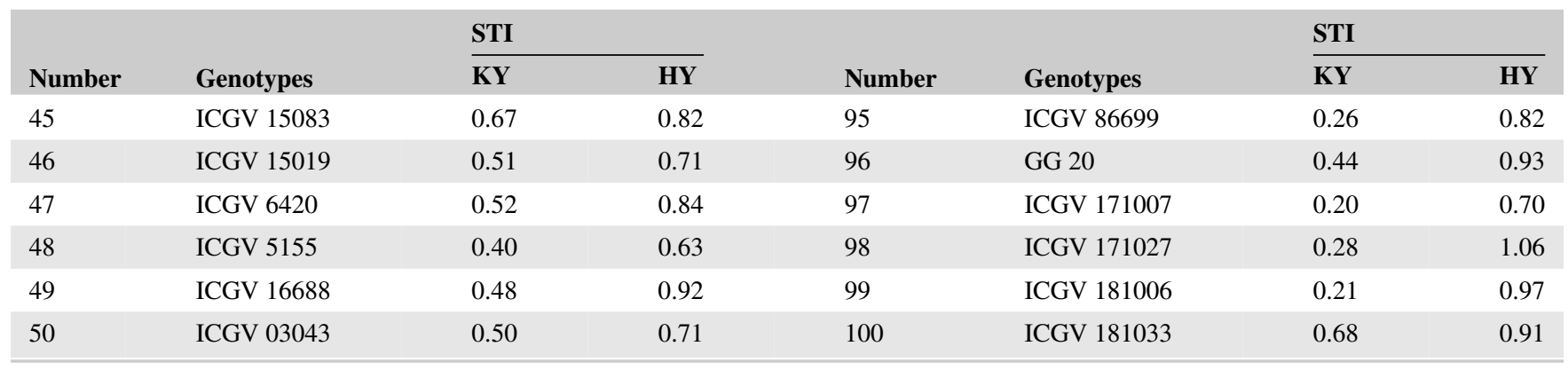

accounted for $9.74 \%$ of total variation. PC5 positively correlated with DM which accounted for $7.64 \%$ of total variation. PC6 positively correlated with DM and negatively correlated with OC which accounted for $6.09 \%$ of total variation.

The relationship between groundnut genotypes and assessed traits based on principal component biplots under DS and NS conditions are presented in Figure 2. Smaller angles between dimension vectors in the same direction indicated high correlation of the variables in terms of discriminating genotypes. Genotypes that are good in a particular trait were plotted closer and furthest to the vector line. Under DS condition, genotypes ICGV 93162, ICGV 10373, ICGV 01260, ICGV 10379, ICGV 10178, ICGV 05155, ICGV 03042, and ICGV 96174 were grouped together based on high NDFDM, ADFDM, ADLDM, and DM, HY, OY, and KY Figure (2a). Genotypes ICGV 181017, ICGV 01491, ICGV 15019, ICGV 181026, ICGV 16005, and ICGV 181063 excelled with high OAC. Genotypes ICGV 171007, ICGV 181063, ICGV 171039, ICGV 181039, ICGV 93261, GPBD 4, and ICGV 13219 were grouped together and possessed high ME, IVODM, NC, and TPC.

Under NS condition, genotypes ICGV 7220, ICGV 06039, ICGV 05155, ICGV 03287, ICGV 06175, ICGV 14001, ICGV 00211 and ICGV 11396 were grouped together recording high $\mathrm{KY}$, OY and OC (Figure 2b). Genotypes ICGV 181017, ICGV 181026, ICGV 181063, ICGV 181489, ICGV 181006, ICGV 16005 and ICGV 15083 were grouped together based on high dry matter content, HY, and OAC. Genotypes ICGV 171007, ICGV 13189, ICGV 99019, ICGV 86031, ICGV 86590, and ICGV 86699 were excelling in NC, ME, IVODM, and PC.

\subsection{Cluster analysis among groundnut genotypes based on KY, HY, and kernel and fodder quality parameters}

Cluster analysis showing the grouping of 100 groundnut genotypes based on KY and HY, and kernel and fodder quality traits are summarized in Table 7 and Figure 3. The test genotypes were allocated into 12 genetic groups. Cluster 11 and 12 comprised of high kernel- and oil-yielding genotypes with mean of $1.72 \mathrm{t} \mathrm{ha}^{-1}$ and $0.84 \mathrm{t} \mathrm{ha}^{-1}$. Genotypes with high OC ( $>49.5 \%)$ were grouped in Clusters 8 and 12. Clusters 1 and 2 comprised of high OAC groundnut genotypes with mean values of 65.57 and $66 \%$, respectively. Conversely, Clusters 1 and 2 consisted of genotypes with lower LACs of $<16 \%$. Genotypes with high NC, IVODM, and ME were grouped in Clusters 4 and 5. Genotypes with higher HY possessing good haulm fodder qualities were grouped in Cluster 6. In this cluster, genotypes ICGV 01490, ICGV 96266, ICGV 93162, ICGV 98077, ICGV 11422, and ICGV 11418 recorded the highest mean $\mathrm{HY}\left(\geq 6.5 \mathrm{t} \mathrm{ha}^{-1}\right)$, NC $(\geq 2.75 \%)$, IVODM $(\geq 62 \%)$, and $\mathrm{ME}(\geq 8.5 \%)$.

\section{4 | DISCUSSION}

Groundnut is a key legume crop for food and feed in croplivestock farming systems. It is the main source of cash for small-holder farmers in arid and semi-arid parts of subSaharan Africa and Asia. Despite the multiple uses of groundnut breeding for drought tolerance, high KY and HY, and quality traits have been largely ignored in groundnut improvement programs. As a result, genotypic variation of groundnut germplasm for KY and HY and kernel and haulm quality parameters remains largely unknown, thus limiting selection and development of dual-purpose groundnut cultivars for kernel and haulm production in smallholder crop-livestock systems.

The present study found significant variations in KY and HY, kernel and fodder quality parameters, and drought tolerance among genetically distinctive groundnut genotypes (Table 1). The significant genotype differences observed among the studied groundnut genotypes for KY and HY, and quality traits allowed selection of suitable dual-purpose genotypes (Table 1 ). Also, genotype $\times$ water regime $\times$ year interaction effect was significant for $\mathrm{KY}$ and $\mathrm{HY}$, indicating that the performance of the assessed genotypes varied across seasons and water conditions (Table 1). Groundnut genotypes ICGV 7222, ICGV 10143, ICVG 06040, ICGV 03042, and ICGV 06175 were selected with marked drought tolerance and 


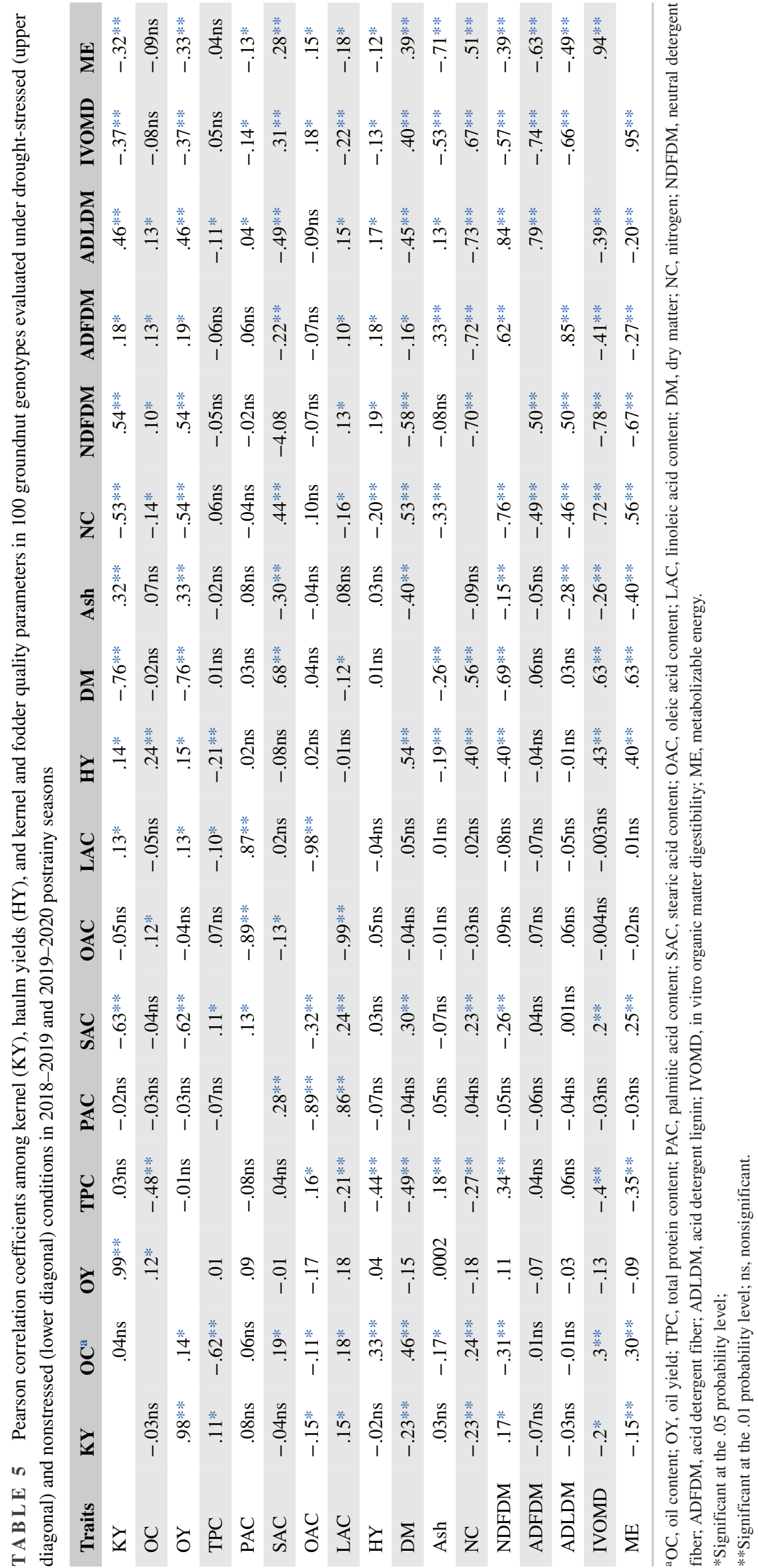


TA B L E 6 Principal component scores, Eigenvalues, variances of kernel yield (KY), oil and haulm fodder quality parameters among 100 groundnut genotypes evaluated under drought-stressed and nonstressed conditions in the 2018-2019 and 2019-2020 postrainy seasons

\begin{tabular}{|c|c|c|c|c|c|c|c|c|c|c|c|}
\hline \multirow[b]{2}{*}{ Traits } & \multicolumn{5}{|c|}{ Drought-stressed } & \multicolumn{6}{|c|}{ Nonstressed } \\
\hline & PC1 & PC2 & PC3 & PC4 & PC5 & PC1 & PC2 & PC3 & PC4 & PC5 & PC6 \\
\hline KY & .11 & .16 & .75 & .02 & .62 & .07 & .63 & -.35 & .52 & .43 & .06 \\
\hline OY & .14 & .17 & .70 & .10 & .67 & .11 & .65 & -.29 & .49 & .47 & -.02 \\
\hline TPC & -.37 & .05 & .49 & -.40 & -.18 & -.14 & -.05 & -.49 & .29 & -.43 & .45 \\
\hline SAC & .00 & -.48 & .10 & .17 & -.09 & -.37 & .42 & .25 & .25 & -.26 & .01 \\
\hline $\mathrm{OAC}$ & -.48 & .81 & -.20 & -.18 & .09 & .42 & -.80 & -.34 & .07 & .11 & -.10 \\
\hline LAC & .49 & -.79 & .19 & .20 & -.06 & -.39 & .81 & .35 & -.09 & -.10 & .07 \\
\hline HY & .32 & .24 & -.35 & .45 & .36 & .15 & -.40 & .58 & -.05 & .34 & .15 \\
\hline $\mathrm{DM}$ & .24 & .13 & -.47 & .37 & .29 & .19 & -.29 & .39 & .10 & .43 & .59 \\
\hline ADFDM & .85 & .35 & -.07 & -.15 & -.21 & .89 & .20 & .14 & .05 & -.15 & .05 \\
\hline ADLDM & .78 & .38 & .04 & .07 & -.35 & .78 & .09 & .33 & .26 & -.18 & .17 \\
\hline IVOMD & -.83 & -.04 & -.01 & .45 & -.10 & -.73 & -.45 & .16 & .39 & .03 & -.12 \\
\hline ME & -.70 & .07 & .22 & .54 & -.23 & -.54 & -.35 & .18 & .61 & -.16 & -.22 \\
\hline Eigenvalue & 4.37 & 2.95 & 2.39 & 2.04 & 1.74 & 4.14 & 3.69 & 2.21 & 1.66 & 1.30 & 1.03 \\
\hline Proportion variance, $\%$ & 25.71 & 17.36 & 14.08 & 12.00 & 10.22 & 24.38 & 21.68 & 13.02 & 9.74 & 7.64 & 6.09 \\
\hline Cumulative variance, $\%$ & 25.71 & 43.06 & 57.14 & 69.13 & 79.35 & 24.38 & 46.06 & 59.07 & 68.81 & 76.45 & 82.54 \\
\hline
\end{tabular}

OC, oil content; OY, oil yield; TPC, total protein content; PAC, palmitic acid content; SAC, stearic acid content; OAC, oleic acid content; LAC, linoleic acid content; HY, haulm yield; DM, dry matter; NC, nitrogen content; NDFDM, neutral detergent fiber; ADFDM, acid detergent fiber; ADLDM, acid detergent lignin; IVOMD, in vitro organic matter digestibility; ME, metabolizable energy.

possessing high STI values for KY (Table 4). Also, genotypes ICGV 01260, ICGV 99241, ICGV 96266, ICGV 171027, and ICGV 01491 recorded high STI values for HY. The stable yield performance of these genotypes in the two environments suggests that these genotypes can be used in groundnut breeding to exploit their drought tolerance and yield potentials.

Agronomic traits such as KY and HY are key attributes for selection and development of dual-purpose groundnut cultivars (Pande et al., 2005). In the present study, genotypes ICGV 10143, ICGV 7222, ICGV 6040, ICGV 03042, and ICGV 06039 were high kernel and oil yielders (Table 3; Supplemental Table S2). Also, genotypes ICGV 01490, ICGV 96266, ICGV 93162, ICGV 98077, ICGV 11422, and ICGV 11418 were the highest haulm yielders and possessed better fodder quality traits such as NC, IVODM, and ME (Table 4; Supplemental Table S3). Moreover, genotypes such as ICGV 10178, ICGV 01260, ICGV 06175, and ICGV 10379 produced both high $\mathrm{KY}$ and $\mathrm{HY}$ and therefore making them ideal candidates for production in mixed crop-livestock farming systems (Tables 3, 4). In addition, kernel and haulm quality traits such as high OAC, TPC, and OAC, reduced NDFDM, ADFDM, and ADLDM, and higher NC, IVODM, and ME are distin- guished traits for selection of groundnut genotypes for production (Nigam, 2014; Samireddypalle et al., 2017). Genotypes ICGV 06146, ICGV 11380, ICGV 14030, ICGV 13189, and ICGV 7222 recorded high protein contents (Table 3; Supplemental Table S2). Genotypes ICGV 1279, ICGV 6420, ICGV 5155, ICGV 97087, and ICGV 99241 were best performers with high OC, whereas CGV 181017, ICGV 01491, ICGV 15019, ICGV 181026, ICGV 16005, and ICGV 181063 were identified as high OAC genotypes (Supplemental Table S2). All the test genotypes that recorded higher OAC under both conditions showed lower LAC $(<13 \%)$. Low oleic/linoleic ratio enhances the stability and shelf-life of groundnut oil and other groundnut derived products (Achola et al., 2017). Genotypes ICGV 92121, ICGV 86590, ICGV 93161, ICGV GG 20, and ICGV 171007 had high NC, IVODM, and ME, and the lowest mean NDFDM, ADFDM, and ADLDM under both DS and NS conditions. The present study identified divergent parental lines for groundnut breeding for enhanced KY and HY, and kernel and fodder quality. Genotypes ICGV 7222, ICGV 10143, ICGV 6040, ICGV 03042, ICGV 06175, ICGV 01260, ICGV 99241, ICGV 96266, ICGV 171027, and ICGV 01491 possessing drought tolerance are recommended for cultivar development under DS environments (Table 4). 
T A B L E 7 Grouping of 100 groundnut genotypes evaluated under drought-stressed and nonstressed conditions across 2018-2019 and 2019-2020 postrainy seasons

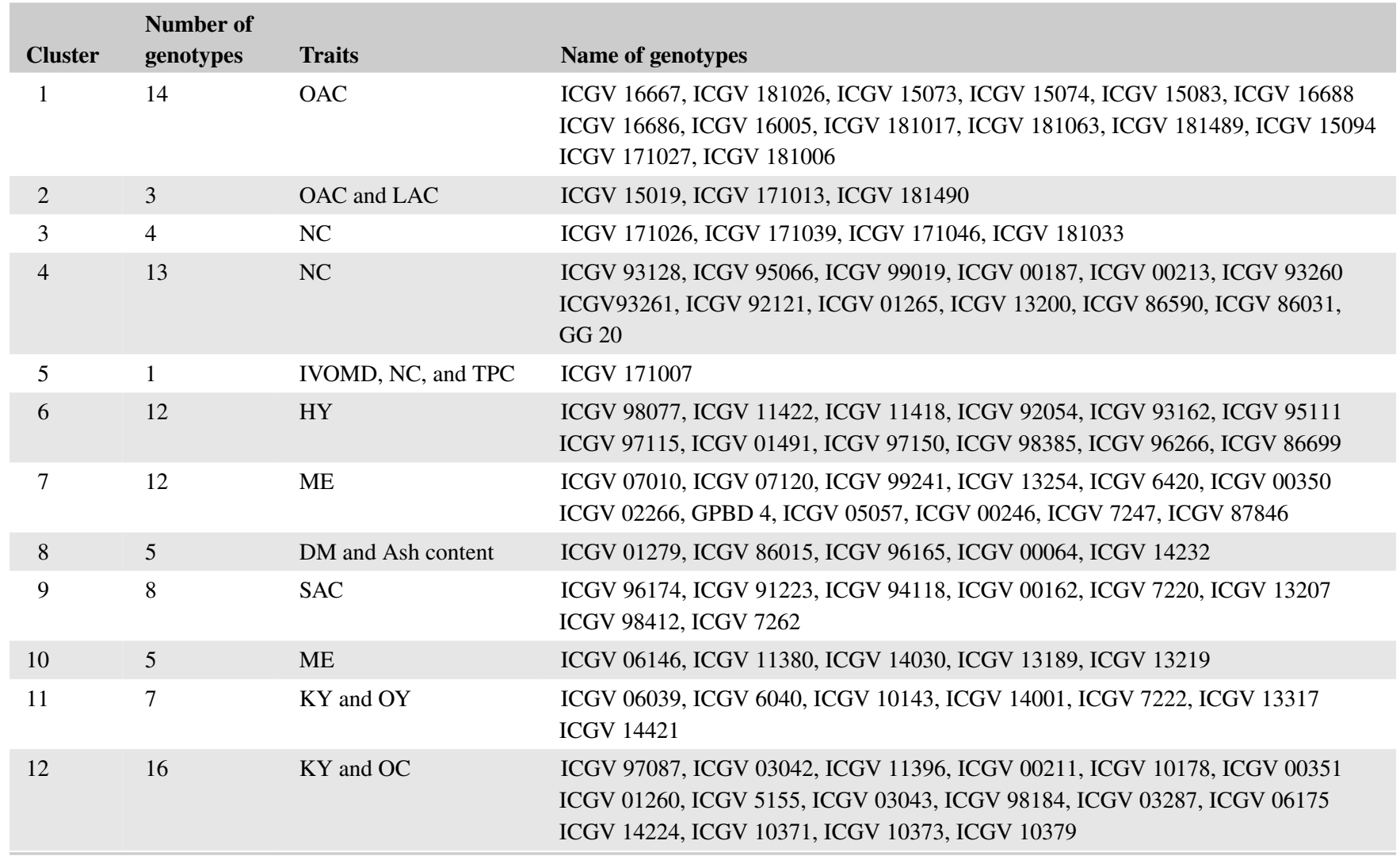

OAC, oleic acid content; LAC, linoleic acid content; NC, nitrogen content; IVOMD, in vitro organic matter digestibility; TPC, total protein content; HY, haulm yield; ME, metabolizable energy; DM, dry matter; SAC, stearic acid content; KY, Kernel yield; OY, oil yield; OC, Oil content.

Comparison across subspecies for KY and HY, and quality traits revealed the Virginia bunch (subspecies hypogaea) recorded slightly higher values for several traits including OC, OAC, HY, DM, NC, ADFDM, and ADLDM (Figure 1). These allowed identification of genotypes with desirable kernel quality, HY, and fodder quality. The Spanish bunch groundnuts have higher OC than other types of groundnuts including Virginia groundnut (Nigam, 2014). The highest mean OC recorded for Virginia subspecies (Figure 1) is probably due to the long intercrosses between the two subspecies. Therefore, groundnut genotypes belonging to the Virginia are useful genetic resources for the development of high oil groundnut cultivars. Also, Virginia groundnuts are late maturing than Spanish bunch groundnuts (Krapovickas \& Gregory, 1994). The high HY recorded by the Virginia subspecies may offer opportunity to improve biomass production. Despite a lack of statistical significance difference, Virginia subspecies comprised of genotypes with high OAC content, but low LAC compared to the Spanish subspecies. These imply that the variability within the Virginia subspecies for majority of the assessed traits can be exploited through selection for developing high oleic groundnut cultivars.

Associations of $\mathrm{KY}$ and $\mathrm{HY}$ and quality is key to design breeding strategies for development of dual-purpose ground- nut genotypes. Under DS condition, OC exhibited low and positive correlation with $\mathrm{OY}$ and $\mathrm{OAC}$, suggesting selection for higher OC result in improved OY and OAC. Haulm yield exhibited positive and significant correlation with $\mathrm{OY}$ and OC under DS and NS conditions, suggesting that these traits can be simultaneously improved via selection. Haulm quality traits such as NC, IVODM, and ME exhibited negative relationships with HY under DS condition (Table 5). Contrastingly, these traits showed positive correlations with $\mathrm{HY}$ under NS condition, underlying the causal role of water deficit contributing for the trade-off between haulm quality traits and $\mathrm{HY}$ (Table 5). This limits simultaneous selection and improvement of the of HY and quality traits under DS condition. Drought stress affects the symbiotic nitrogen fixation capacity of the crop, and consequently leads to reduced NC and haulm digestibility which results in low ME (Blümmel et al., 2012).

In the present study, positive and significant correlations were exhibited between NC and IVODM, NC and ME, and IVODM and ME under both water conditions (Table 5). Further, these traits influence haulm quality. Negative and significant correlation were detected with the indigestible haulm quality traits such as NDFDM, ADFDM, and ADLDM under both conditions. This suggests that NC, IVODM, and ME can be simultaneously improved through selection. Nitrogen 

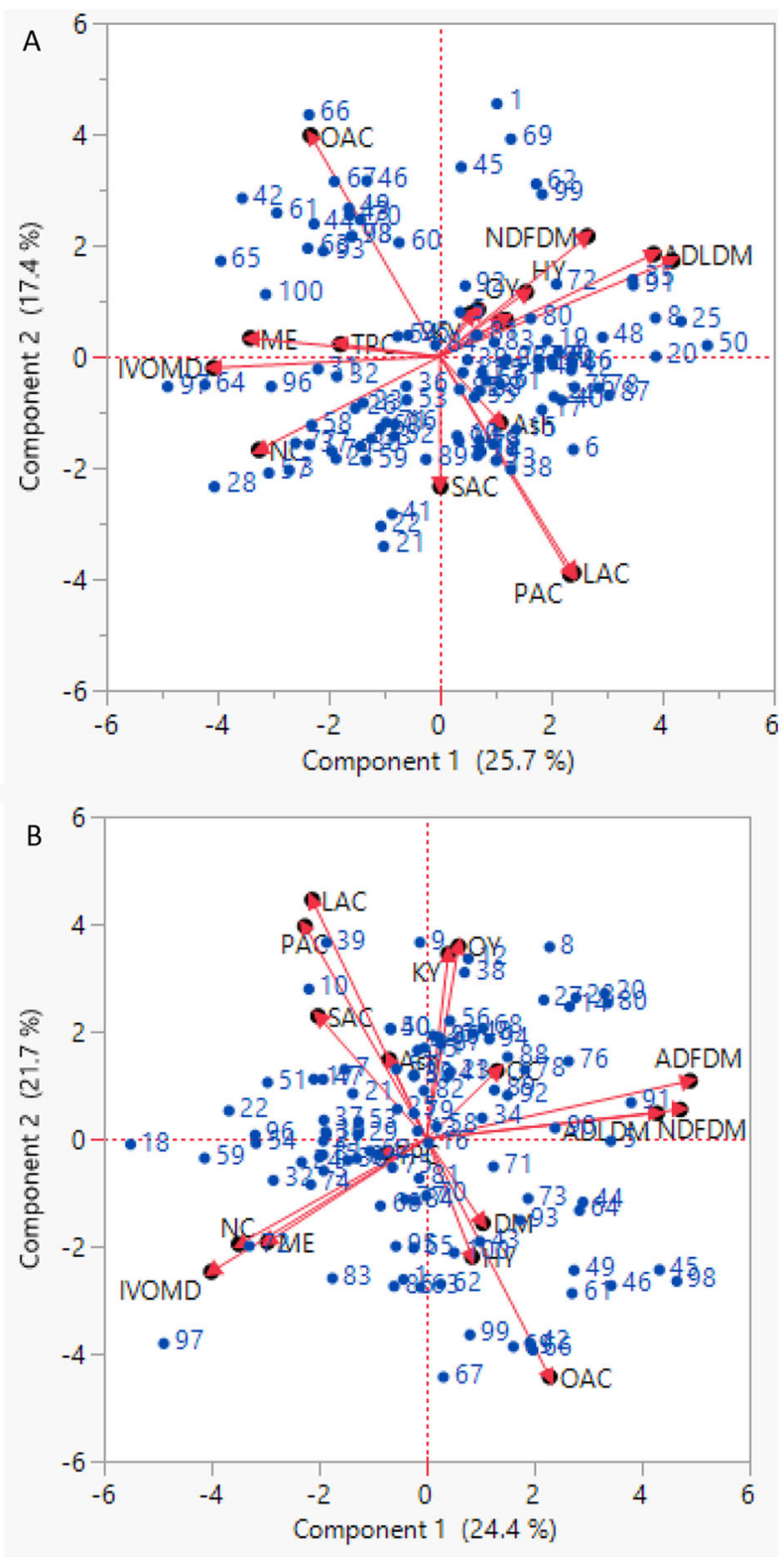

F I G U R E 2 Principal components biplot showing the relationship between assessed traits among 100 groundnut genotypes under drought-stressed (a) and nonstressed (b) conditions evaluated across the 2018-2019 and 2019-2020 postrainy seasons at the International Crops Research Institute for the Semi-Arid Tropics, India. KY, Kernel yield; OC, Oil content; OY, oil yield; TPC, total protein content;

PAC, palmitic acid content; SAC, stearic acid content; OAC, oleic acid content; LAC, linoleic acid content; HY, haulm yield; NC, nitrogen content; IVOMD, in vitro organic matter digestibility;

ME, metabolizable energy. See code of genotypes in Supplemental Table S1

content is an important haulm quality trait and influence $\mathrm{KY}$ due remobilization of nitrogen resources to pods (Blümmel et al., 2012). Under DS condition, negative correlations displayed between NC with KY and HY suggested the effect of

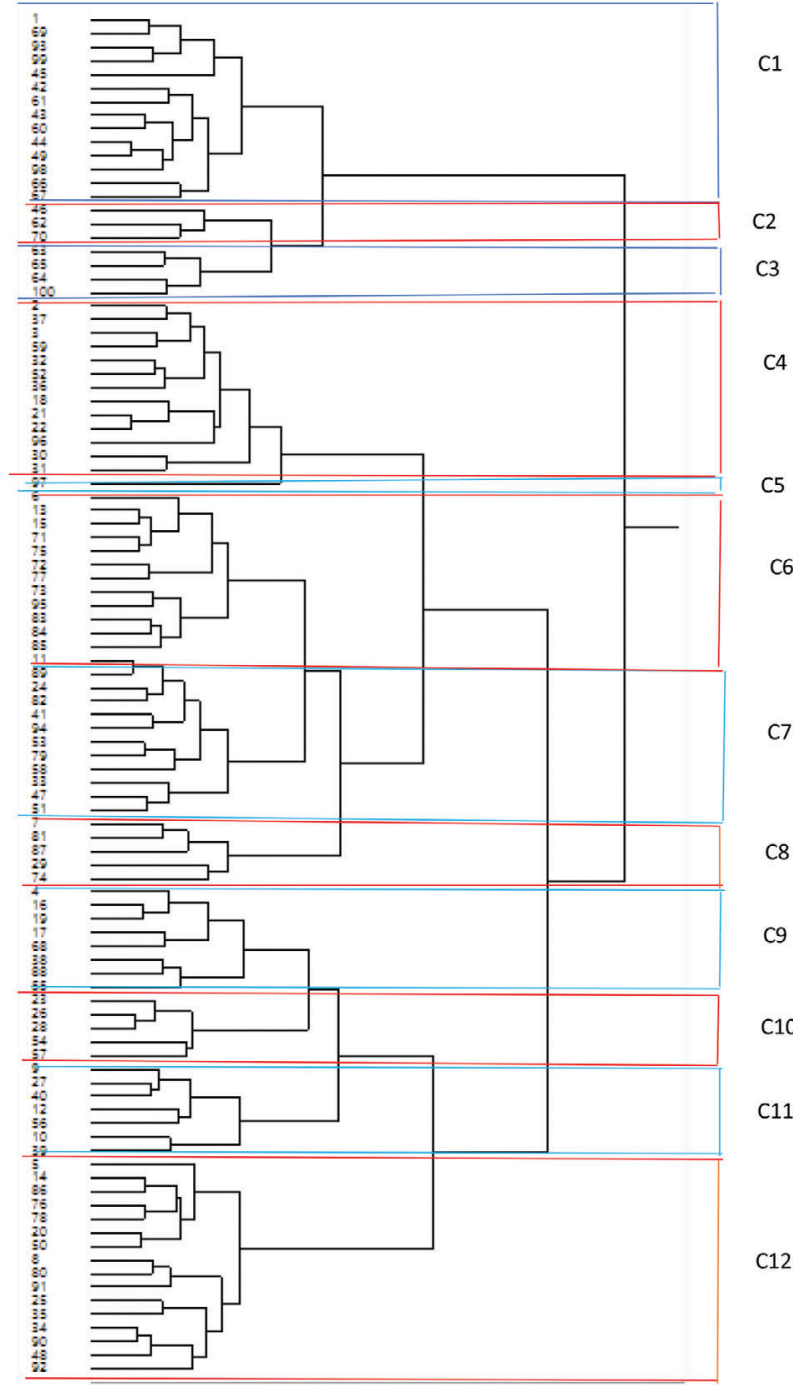

F I G U R E 3 Hierarchical clustering using Ward's method showing groupings of 100 groundnut genotypes assessed based on kernel and haulm yields, and kernel and fodder quality parameters under drought-stressed and non-stressed conditions when genotypes were assessed in the 2018-2019 and 2019-2020 postrainy seasons at the International Crops Research Institute for the Semi-Arid Tropics, India. See code of genotypes in Supplemental Table S1

drought on groundnut biomass and KY production with consequences on the source-sink relationship for nitrogen.

Selecting genotypes based on multiple traits enables to enhance the genetic gains of target traits. Under DS condition, the principal component analysis indicated high contribution and strong association of NDFDM, ADFDM, ADLDM, and HY to the first principal component (Table 6; Figure 2). Oleic acid content and ME correlated with the second principal component, suggesting these traits have much influence during selection and can be simultaneously selected and improved. Under NS condition, NDFDM, ADFDM, ADLDM, OC, KY, AND OAC were main contributors in the 
first principal component (Table 6; Figure 2). These traits can also be simultaneously selected for breeding.

\section{5 | CONCLUSIONS}

A well-characterized groundnut germplasm collection is essential to select unique genotypes with drought-tolerance and high kernel, oil, and HY and quality. The study revealed the presence of marked genetic variability among the tested groundnut genotypes for the measured traits which can be exploited in groundnut breeding. Kernel yield and HY were not inversely related. Low correlation between $\mathrm{KY}$ and HY under DS and NS, suggests independent selection and improvement of the two traits. Strong correlations among the haulm quality traits in both moisture conditions provides an opportunity for breeding of these traits in parallel and developing high haulm fodder quality under DS and optimum conditions. The following genotypes: ICGV 10178, ICGV 01260, ICGV 06175 and ICGV 10379 expressed high KY and HY, and CGV 181017, ICGV 01491, ICGV 15019, ICGV 181026, ICGV 16005, and ICGV 181063 had higher OAC. Further, genotypes ICGV 7222, ICGV 10143, ICGV 6040, ICGV 03042, ICGV 06175, ICGV 01260, ICGV 99241, ICGV 96266, ICGV 171027, and ICGV 01491 were relatively drought tolerant. The above genotypes are recommended for production or breeding drought-stress tolerant groundnut varieties with high kernel and fodder yields and quality attributes.

\section{F U N D I N G}

This work was financially supported by the Organization of the Petroleum Exporting Countries (OPEC) Fund for International Development (OFID), International Foundation for Science (IFS), Haramaya University and University of KwaZuluNatal, and conducted under CGIAR Research Program on Grain Legume and Dry Land Cereals (CRP-GLDC).

\section{ACKNOWLEDGMENTS}

Authors are very thankful to Groundnut Breeding Program and International Livestock Research Institute (ILRI) based at ICRISAT, India for the technical assistance during the analysis of groundnut haulms for fodder quality and digestibility. ICRISAT is thanked for providing the groundnut germplasm used in the study.

\section{AUTHOR CONTRIBUTIONS}

Seltene Abady: Conceptualization; Data curation; Formal analysis; Methodology; Writing-original draft. Hussein Shimelis: Conceptualization; Methodology; Project administration; Resources; Validation; Writing-original draft. Janila Pasupuleti: Conceptualization; Methodology; Project administration; Supervision; Resources. Jacob Mashilo: Con- ceptualization; Formal analysis; Resources; Validation. Sunil Chaudhari: Resources. Surendra S. Manohar: Resources

\section{CONFLICTOF INTEREST}

The authors report no conflict of interest.

\section{O R C I D}

Seltene Abadya (D) https://orcid.org/0000-0002-9618-0741 Hussein Shimelis (10) https://orcid.org/0000-0003-2793-8392 Janila Pasupuleti (10 https://orcid.org/0000-0003-2583-9630 Jacob Mashilo (1D https://orcid.org/0000-0001-9015-043X Sunil Chaudhari @ https://orcid.org/0000-0003-1441-3327

\section{R E F E R E N C E S}

Abady, S., Shimelis, H., \& Janila, P. (2019).. Farmers' perceived constraints to groundnut production, their variety choice and preferred traits in eastern Ethiopia: Implications for drought-tolerance breeding. Journal of Crop Improvement, 33, 1-17. https://doi.org/10.1080/ 15427528.2019.1625836

Achola, E., Tukamuhabwa, P., Adriko, J., Edema, R., Mwale, S. E., Gibson, P., \& Okello, D. K. (2017).. Composition and variation of fatty acids among groundnut cultivars in Uganda. African Crop Science Journal, 25, 291-299. https://doi.org/10.4314/acsj.v25i3.3

Ahmed, H., Yoder, J., de Glanville, W., Davis, A., Kibona, T. J., Mmbaga, B. T., Lankester, F., Swai, F. E., \& Cleaveland, S. (2019).. Economic burden of livestock disease and drought in northern Tanzania. Journal of Development and Agricultural Economics, 11, 140-151.

Andersen, P. C., Hill, K., Gorbet, D. W., \& Brodbeck, B. V. (1998).. Fatty acid and amino acid profiles of selected peanut cultivars and breeding lines. Journal of Food Composition and Analysis, 11, 100111. https://doi.org/10.1006/jfca.1998.0565

Bishi, S. K., Kumar, L., Dagla, M. C., Mahatma, M. K., Rathnakumar, A. L., Lalwani, H. B., \& Misra, J. B. (2013).. Characterization of Spanish peanut germplasm (Arachis hypogaea L.) for sugar profiling and oil quality. Industrial Crops and Products, 51, 46-50. https://doi.org/10. 1016/j.indcrop.2013.08.050

Blummel, M., Ratnakumar, P., \& Vadez, V. (2012).. Opportunities for exploiting variations in haulm fodder traits of intermittent drought tolerant lines in a reference collection of groundnut (Arachis hypogaea L.). Field Crops Research, 126, 200-206. https://doi.org/10.1016/j. fcr.2011.10.004

Carvalho, M. J., Vorasoot, N., Puppala, N., Muitia, A., \& Jogloy, S. (2017).. Effects of terminal drought on growth, yield and yield components in Valencia peanut genotypes. SABRAO Journal of Breeding and Genetics, 49, 270-279.

Choe, E., \& Min, B. D. (2007).. Chemistry of deep-fat frying oils. Journal of Food Science, 72, 77-86. https://doi.org/10.1111/j.1750-3841. 2007.00352.x

DaSilva, T. E., Detmann, E., Franco Mde, O., Nobre, P. M. N., \& Rocha, G. C. (2016).. Evaluation of digestion procedures in Kjeldahl method to quantify total nitrogen in analyses applied to animal nutrition. Acta Agriculturae Scandinavica. Section A-Animal Science, 38, 45-51. https://doi.org/10.4025/actascianimsci.v38i1. 29171

Deshmukh, D. B., Marathi, B., Sudini, H. K., Variath, M. T., Chaudhari, S., Manohar, S. S., Rani, C. V. D., Pandey, M. K., \& Pasupuleti, J. (2020).. Combining high oleic acid trait and resistance to late leaf 
spot and rust diseases in groundnut (Arachis hypogaea L.). Frontiers in Genetics, 11, 514. https://doi.org/10.3389/fgene.2020.00514

EL Sabagh, A., Hossain, A., Barutcular, C., Gormus, O., Ahmad, Z., Hussain, S., Islam, M., Alharby, H., Bamagoos, A., Kumar, N., Akdeniz, A., Fahad, S., Meena, R. S., Abdelhamid, M., Wasaya, A., Hasanuzzaman, M., Sorour, S., \& Saneoka, H. (2019).. Effects of drought stress on the quality of major oilseed crops: Implications and possible mitigation strategies-A review. Applied Ecology and Environmental Research, 17, 4019-4043. https://doi/10.15666/aeer/ 1702_40194043

Falke, A. B., Hamidou, F., Halilou, O., \& Harou, A. (2019).. Assessment of groundnut elite lines under drought conditions and selection of tolerance associated traits. Advances in Agriculture, 2019, 1-10. https://doi.org/10.1155/2019/3034278.

Fernandez, G. C. J. (1992).. Effective selection criteria for assessing plant stress tolerance. Proceedings of the International Symposium on Adaptation of Vegetables and other Food Crops in Temperature and Water Stress (pp. 257-270), August 13-16, 1992, Shenhua, Taiwan.

Hamidou, F., Ratnakumar, P., Halilou, O., Mponda, O., Kapewa, T., Monyo, E., Faye, I., Ntare, B. R., Nigam, S. N., Upadhyaya, H. D., \& Vadez, V. (2012).. Selection of intermittent drought tolerant lines across years and locations in the reference collection of groundnut (Arachis hypogaea L.). Field Crops Research, 126,189-199. https://doi.org/10.1016/j.fcr.2011.10.009

Hill, J., Becker, H. C., \& Tigerstedt, P. M. (2012).. Quantitative and ecological aspects of plant breeding. Berlin: Springer Science \& Business Media.

Janila, P., Nigam, S. N., Pandey, M. K., Nagesh, P., \& Varshney, R. K. (2013).. Groundnut improvement: Use of genetic and genomic tools. Frontiers in Plant Science, 4, 1-16. https://doi.org/10.3389/fpls.2013. 00023

Janila, P., Nigam, S. N., Abhishek, R., Kumar, V. A., Manohar, S. S., \& Venuprasad, R. (2014).. Iron and zinc concentrations in peanut (Arachis hypogaea $\mathrm{L}$.) seeds and their relationship with other nutritional and yield parameters. Journal of Agricultural Science, 153, 975-994. https://doi.org/10.1017/S0021859614000525

Janila, P., Variath, M. T., Pandey, M. K., Desmae, H., Motagi, B. N., Okori, P., Manohar, S. S., Rathnakumar, A. L., Radhakrishnan, T., Boshou, L. B., \& Varshney, R. K. (2016).. Genomic tools in groundnut breeding program: Status and perspectives. Frontiers in Plant Science, 7, 289. https://doi.org/10.3389/fpls.2016.00289

Janila, P., Manohar, S., Deshmukh, D., Chaudhari, S., Papaiah, V., \& Variath, M. T. (2018).. Standard operating procedures for groundnut breeding and testing. Documentation ICRISAT.

Janila, P., Radhakrishnan, T., Murali, T. V., Bera, S. K., Dobariya, K. L., Nigam, S. N., Varshney, R. K., Pandey, M. K., Manohar, S. S., Manivannan, N., \& Vasanthi, R. P., (2018).. High oleic peanuts for Asia and Africa to meet the needs of the food processing industries. Case study. Science forum, Stellenbosch, South Africa.

Joshi, A. K., Kumar, U., Mishra, V. K., Chand, R., Chatrath, R., Naik, R., Biradar, S., Singh, R. P., Budhlakoti, N., Devulapalli, R., \& Blümmel, M. (2019).. Variations in straw fodder quality and grain-Straw relationships in a mapping population of 287 diverse spring wheat lines. Field Crops Research, 243, 107627. https://doi.org/10.1016/j. fcr.2019.107627

Kadim, I. T., Mahgoub, O., Al-Marzooqi, W., \& Annamalai, K. (2005).. Prediction of crude protein, extractable fat, calcium and phosphorus contents of broiler chicken carcasses Using Near-infrared Reflectance
Spectroscopy. Asian-Australasian Journal of Animal Sciences, 8, 1036-1040. https://doi.org/10.5713/ajas.2005.1036

Krapovickas, A., \& Gregory, W. (1994).. Taxonomía del género Arachis (Leguminosae). Bonplandia, 8, 1-186.

Mertens, D. R. (2000).. Interpretation of forage analysis reports. In 30th National alfalfa symposium. Las Vegas, NV.

Nawade, B., Mishra, G. P., Radhakrishnan, T., Dodia, S. M., Ahmad, S., Kumar, A., \& Kundu, R. (2018).. High oleic peanut breeding: Achievements, perspectives, and prospects. Trends in Food Science \& Technology, 78, 107-119. https://doi.org/10.1016/j.tifs.2018. 05.022 .

Ngcamu, B. S., \& Chari, F., (2020).. Drought influences on food insecurity in Africa: A Systematic literature review. International Journal of Environmental Research and Public Health, 2020, 1-17. https://doi.org/10.3390/ijerph17165897

Nigam, S. N. (2014).. Groundnut at a glance. p. 121.

Ojiewo, C. O., Janila, P., Bhatnagar-Mathur, P., Pandey, M. K., Desmae, H., Okori, P., Mwololo, J., Ajeigbe, H., Njuguna-Mungai, E., Muricho, G., Akpo, E., Gichohi-Wainaina, W. N., Variath, M. T., Radhakrishnan, T., Dobariya, K. L., Bera, S. K., Rathnakumar, A. L., Manivannan, N., Vasanthi, R. P., \& Varshney, R. K. (2020).. Advances in crop improvement and delivery research for nutritional quality and health benefits of groundnut (Arachis hypogaea L.). Frontiers in Plant Science, 11, 29. https://doi.org/10.3389/fpls.2020.00029

Oteng-Frimpong, R., Konlan, S. P., \& Denwar, N. N. (2017).. Evaluation of selected groundnut (Arachis hypogaea L.) lines for yield and haulm nutritive quality traits. International Journal of Agronomy, 2017, 1-9. https://doi.org/10.1155/2017/7479309

Oteng-Frimpong, R., Baba, Y. K., Danful, R., Akromah, R., WirekoKena, A., \& Forson, S. (2019).. Modeling groundnut (Arachis hypogaea L.) performance under drought conditions. Journal of Crop Improvement, 33, 125-144. https://doi.org/10.1080/15427528.2018. 1542363

Pande, S., Upadhyaya, H. D., Narayana, R. J., Lakshmi, R. P., \& Parthasarathy, R. (2005).. Promotion of integrated disease management for ICGV 91114, a dual-purpose, early maturing groundnut variety for rainfed areas (Information Bulletin No. 68). Patancheru, India: International Crops Research Institute for the Semi-Arid Tropics.

Pandey, M. K., Monyo, E., Ozias-Akins, P., Liang, X., Guimarães, P., Nigam, S. N., Upadhyaya, H. D., Janila, P., Zhang, X., Guo, B., Cook, D. R., Bertioli, D. J., Michelmore, R., \& Varshney, R. K. (2012).. Advances in Arachis genomics for peanut improvement. Biotechnology Advances, 30, 639-651. https://doi.org/10.1016/j.biotechadv. 2011.11.001

Pereira, J. W. L., Albuquerque, M. B., Melo Filho, P. A., Nogueira, R. J. M. C., Lima, L. M., \& Santos, R. C. (2016).. Assessment of drought tolerance of peanut cultivars based on physiological and yield traits in a semiarid environment. Agricultural Water Management, 166, 70 76. https://doi.org/10.1016/j.agwat.2015.12.010

R Core Team (2020).. R: A language and environment for statistical computing. R Foundation for Statistical Computing. https://www. R-project.org/.

Ren, X. Jiang, H., Yan, Z., Chen, Y., Zhou, X., Huang, L., Lei, Y., Huang, J., Yan, L., Qi, Y., Wei, W., \& Liao, B. (2014).. Genetic diversity and population structure of the major peanut (Arachis hypogaea L.) cultivars grown in China by SSR markers. PLOS ONE, 9(2), e88091. https://doi.org/10.1371/journal.pone.0088091 
Samireddypalle, A., Boukar, O., Grings, E., Fatokun, C. A., Kodukula, P., Devulapalli, R., Okike, I., \& Blümmel, M. (2017).. Cowpea and groundnut haulms fodder trading and its lessons for multidimensional cowpea improvement for mixed crop livestock systems in West Africa. Frontiers in Plant Science, 8, 30. https://doi.org/10.3389/fpls.2017. 00030

Sarvamangala, C., Gowda, M. V. C., \& Varshney, R. K. (2011).. Identification of quantitative trait loci for protein content, oil content and oil quality for groundnut (Arachis hypogaea L.). Field Crops Research, 122, 49-59. https://doi.org/10.1016/j.fcr.2011.02.010

Shasidhar, Y., Variath, M. T., Vishwakarma, M. K., Manohar, S. S., Gangurde, S. S., Sriswathi, M., Sudini, H. K., Dobariya, K. L., Bera, S. K., Radhakrishnan, T., Pandey, M. K., Janila, P., \& Varshney, R. K. (2020).. Improvement of three popular Indian groundnut varieties for foliar disease resistance and high oleic acid using SSR markers and SNP array in marker-assisted backcrossing. The Crop Journal, 8, 115. https://doi.org/10.1016/j.cj.2019.07.001

Singh, A. K., \& Nigam, S. N. (2016). Arachis gene pools and genetic improvement in groundnut. In V. R. Rajpal, S. M. Rao, S. N. Raina (Eds.), Gene pool diversity and crop improvement, sustainable development and biodiversity 10, https://doi.org/10.1007/ 978-3-319-27096-8_2

Upadhyaya, H. D., Swamy, B. P. M., Goudar, P. V. K., Kullaiswamy, B. Y., \& Singh, S. (2005).. Identification of diverse groundnut germplasm through multienvironment evaluation of a core collection for Asia. Field Crops Research, 93, 293-299. https://doi.org/10.1016/ j.fcr.2004.10.007
Yol, E., Ustun, R., Golukcu, M., \& Uzun, B. (2017).. Oil content, oil yield and fatty acid profile of groundnut germplasm in Mediterranean climates. Journal of the American Oil Chemists' Society, 94, 787-804. https://doi.org/10.1007/s11746-017-2981-3

Zheng, Z., Sun, Z., Fang, Y., Qi, F., Liu, H., Miao, L., Du, P., Shi, L., Gao, W., Han, S., Dong, W., Tang, F., Cheng, F., Hu, H., Huang, B., \& Zhang, X. (2018).. Genetic diversity, population structure, and botanical variety of 320 global peanut accessions revealed through tunable genotyping-by-sequencing. Scientific Reports, 8, 14500. https:// doi.org/10.1038/s41598-018-32800-9

\section{SUPPORTING INFORMATION}

Additional supporting information may be found online in the Supporting Information section at the end of the article.

How to cite this article: Abady S, Shimelis H, Janila P, Mashilo J, Chaudhari S, Manohar SS. Assessment of the genetic diversity of groundnut (Arachis hypogaea L.) genotypes for kernel yield, oil and fodder quantity and quality under drought conditions. Crop Science. 2021;1-18.

https://doi.org/10.1002/csc2.20483 